Summer 2008

\title{
Globalization and Housing Rights
}

\author{
Padraic Kenna \\ National University of Ireland
}

Follow this and additional works at: https://www.repository.law.indiana.edu/ijgls

Part of the International Law Commons, and the Social Welfare Law Commons

\section{Recommended Citation}

Kenna, Padraic (2008) "Globalization and Housing Rights," Indiana Journal of Global Legal Studies: Vol. 15 :Iss. 2 , Article 1.

Available at: https://www.repository.law.indiana.edu/ijgls/vol15/iss2/1

This Article is brought to you for free and open access by the Law School Journals at Digital Repository @ Maurer Law. It has been accepted for inclusion in Indiana Journal of Global Legal Studies by an authorized editor of Digital Repository @ Maurer Law. For more information, please contact rvaughan@indiana.edu.

\section{$\Psi$}

JEROME HALL LAW LIBRARY

INDIANA UNIVERSITY

Maurer School of Law
Blooming ton 


\title{
Globalization and Housing Rights
}

\author{
Padraic KenNA*
}

\begin{abstract}
This article seeks to explore the relationship between the growing phenomenon of globalization and the field of housing rights. I begin with a general description of globalization, and move on to discuss its effect on homelessness, and on housing systems across the world. I examine the role of global corporations; the globalization of housing finance and real estate investment; the reordering of cities and slums; the idea of the minimalist state; and the effects of privatization. I examine the rise of governance networks and how they have created new patterns of making law; globalization's effect on housing policy; and its effects on the movement of people. Next I look to the idea of housing rights and some specific instances of their development through the United $\mathrm{Na}$ tions, the Council of Europe, and the European Union. These rights may offer the possibility of mediating the excesses of neo-liberal globalization and promote social equality and inclusion. I conclude with a call to reconsider traditional liberal legal models and housing-as-property regimes, and recommend the legal concept of the "home" may be a more appropriate base model for housing rights in a globalizing world.
\end{abstract}

\section{INTRODUCTION}

Today, globalization or global neo-liberalism is seen as ubiquitous. It is accredited with dramatic developments in all areas of work, consumption, technology, and most areas of modern life. Housing addresses the basic need for human shelter, but also facilitates the essential human requirement for a home. Housing has become

* Lecturer in Law at National University of Ireland, Galway, Ireland. Telephone: 0035391 493230. E-mail: padraic.kenna@nuigalway.ie. I would like to express appreciation for the assistance of Donncha O'Connell, Paul O'Connell, Alan Ahearne, Terry McDonough, and orhers who provided insights and help in preparing this article. This article is developed from a presentation on Globalization and Housing Rights at the Housing Rights in Europe Conference, Helsinki, September 2006. See http://www.ymparisto.fi/download. asp? contentid $=56421 \& l a n=e n$.

Indiana Journal of Global Legal Studies Vol. 15 \#2 (Summer 2008)

CIndiana University School of Law 
the contemporary universal repository of household wealth and equity. Similarly, there is a developing corpus of jurisprudence and literature on human rights with housing rights as an integral element. The impact of these contemporary developments on housing systems, law, and policy has not been widely examined.

This article explores aspects of globalization and housing rights. Part One includes an overview of globalization and its impacts on housing systems worldwide, but particularly in Europe. Part Two outlines the globalization of housing corporations, property rights, housing finance markets and lenders, real estate investment in housing, the reordering of cities and creation of slums, new roles for the state, and globalized migrants and refugees. Part Three examines housing rights as promulgated within international and European legal instruments and precedents, while Part Four attempts to trace contemporary interaction between housing rights and globalized/neo-liberal impacts on housing systems.

The effects of globalization are mediated by states, institutions, and individuals, creating different outcomes based on varying historical political legacies. Many international and regional instruments and monitoring agencies are expanding the definition of housing rights, exhorting states to adopt appropriate policy, legal, and administrative measures. Yet courts regularly act as the final arbiters of individual violations of housing rights at the national level, but increasingly at the regional or supra-national level, addressing key critical structural housing issues expressed as individual disputes. The conflict between historically hallowed property rights and emerging housing rights can mask a deeper gulf, which is both structural and conceptual. Could a modern interpretation of home offer a way forward for housing rights in this age of globalization?

\section{Depicting Globalization}

\section{A. Defining Globalization}

Definitions of globalization are diverse, and the term itself is hotly contested. ${ }^{1}$ Globalization is a generic term used to describe a range of economic, industrial, social, military, and cultural changes that have created high levels of interdepen-

1. See, e.g., Paul Hirst \& Grahame Thompson, Globalization in Question: The International Economy and the Possibilities of Governance (1996); Philluppe LeGrain, Open World: The Truth About Globalization (2004); Roland Robertson, Globalization: Social Theory and Global Culture (1992); Saskia Sassen, Losing Control? Sovereignty in an Age of Globalization (1996). 
dence, interaction, and integration among different parts of the world, between people, and between producers and consumers. ${ }^{2}$

Technological development and communication are key features of globalization, which have also been variously conceived as action at a distance; timespace compression; accelerating interdependence; a shrinking world; and among other concepts, global integration, the reordering of interregional power relations, consciousness of global conditions, and the intensification of interregional connectedness. The local becomes embedded within more expansive sets of interregional relations and networks of power-the global village. ${ }^{3}$

From the information superhighway to the international trade in drugs and arms, to the phenomenal impact of MacWorld, Nike and the global media, the subject of globalization has come to concern all and sundry. At the core of most discussions of the issue is the extraordinary explosion of both technology and information, in ways that have considerably reduced the twin concepts of time and space. In particular, information and communications technology (ICT) has emerged as perhaps the most dominant force in the global system of production, albeit with significant ramifications in all other spheres of contemporary human existence. ${ }^{4}$

Anthony Giddens regards globalization as having four dimensions, involving the world capitalist economy, the nation-state systems, the world military order, ${ }^{5}$

2. There is an important distinction between internationalization and globalization. See David Held et al., Global Transformations: Politics, Economics, and Culture 52-58 (1999).

3. See David Held \& Anthony McGrew, The Great Globalization Debate: An Introduction, in The Global Transformations Reader: An Introduction to the Globalization Debate 1 (David Held \& Anthony McGrew eds., 2d ed. 2003).

4. U.N. Econ. \& Soc. Council [ECOSOC], Sub-Comm. on Promotion and Protection of Human Rights, Preliminary Report: The Realization of Economic, Social and Cultural Rights: Globalization and Its Impact on the Full Enjoyment of Human Rights, If 6, UN Doc. E/CN.4/ Sub.2/2000/13 (June 15, 2000) (prepared by J. Oloka-Onyango \& Deepika Udagama) [hereinafter Preliminary Report].

5. The effects of the globalized world military order on housing have been enormous. Today, more than five million Palestinian refugees continue to be prevented from returning to their homes and recovering their land and properties. See Centre on Housing Rights and Evictions (COHRE) \& BALDI, Ruling Palestine: A History of Legally Sanctioned Jewish-Israeli Seizure of Land in Palestine (2005). See also ECOSOC, Comm. on Human Rights, Economic, Social and Cultural Rights: Report of the Special Rapporteur on Adequate Housing as a Component of the Right to an Adequate Standard of Living, I 35-39, UN Doc. E/CN.4/2005/48 (Mar. 3, 2005) 
and the international division of labor. Globalization primarily involves the intensification of worldwide social relations. ${ }^{6}$

A precise and widely quoted definition of globalization is put forward by David Held and others as "a process (or set of processes) which embodies a transformation in the spatial organization of social relations and transactions-assessed in terms of their extensity, intensity, velocity and impact-generating transcontinental or interregional flows and networks of activity, interaction, or the exercise of power."

Globalization has been described as an ideological construction, a convenient myth, which, in part, helps justify and legitimize the neo-liberal global project, ${ }^{8}$ that is, the creation of a global free market, and the consolidation of Anglo-American capitalism within the world's major economic regions. ${ }^{9}$

Of course, contemporary globalization may be no more than a continuation of centuries old global trade, hugely intensified after the industrial revolution, as addressed by Karl Marx and Frederick Engels in their description of the global nature of capital. ${ }^{10}$ Depicting globalization as the second great transformation, Rhoda Howard-Hassmann supports the view that globalization is the final assault of capitalism on those areas of the globe that previously escaped it, either because of explicit communism or socialist politics "or because capitalism had no interest in the region as a source of capital or resources, a source of workers or a market."1 It now appears that globalization is forcing onto an unwilling world

(prepared by Miloon Kothari) [hereinafter Adequate Housing]. Some three million Afghan refugees in Pakistan face grave uncertainty. The original houses of many have been destroyed, while they have not been provided any alternate land and housing. Indeed, the UN Special Rapporteur on Housing Rights reported in 2003 that top Afghan Ministers were illegally occupying land and demolishing the homes of poor people. In recent years, millions of people have become refugees after their homes were destroyed or seized in globalized conflicts in Bosnia-Herzegovina, Afghanistan, South Africa, Angola, Ethiopia, Sudan, Mozambique, Kosovo and other countries. The globalization of the arms trade ensures continuous conflict worldwide.

6. Anthony Gindens, The Consequences of Modernity 64 (1990).

7. David Held et al., Rethinking Globalization, in The Global Transformations Reader, supra note 3 , at 68 .

8. See generally David Harvey, A Brief History of Neoliberalisms (2005) (giving an excellent account of the development of neo-liberalism).

9. See Tom Hanahoe, America Rules: US Foreign Policy, Globalization and Corporate USA 13 (2003).

10. See Karl Marx et al., Capital: A Critique of Political Economy Vol. 2 (1919).

11. Rhoda Howard-Hassmann, The Second Great Transformation: Human Rights Leapfrogging in the Era of Globalization, 27 Hum. RTs. Q. 1, 5 (2005). 
the conditions of early European capitalism, ignoring the international human rights law that now prohibits those conditions. ${ }^{12}$

The primary agents and institutional focus of contemporary economic global practices are widely identified as transnational corporations. ${ }^{13}$ But the World Bank, the International Monetary Fund (IMF), the World Trade Organization (WTO), commodity and currency exchanges, and international organizations, such as the G8, the Bilderburg Group, ${ }^{14}$ the Trilateral Commission, ${ }^{15}$ and the World Economic Forum, ${ }^{16}$ comprising leading industrialists and politicians, set the agenda and course for corporations, states, and institutions to follow. The United States promotes its policies on banking, labor, and other major economic areas, and many countries have adopted these policies within the phenomenon known as the "Washington Consensus."

not only the US government, but all those institutions and networks of opinion leaders centred in the world's defacto [sic] capital-the IMF, World Bank, think-tanks, politically sophisticated investment bankers, and worldly finance ministers, all those who meet each other in Washington and collectively define the conventional wisdom of the moment ... the belief that Victorian virtue and economic policy - free markets and sound money-is the key to economic development. ${ }^{18}$

Joseph Stiglitz describes the Washington Consensus policies as:

12. Id. at 18 .

13. See Joel Bakan, The Corporation: The Pathological Pursuit of Profit and Power (2004).

14. See Jonathan Duffy, Bilderberg: The Ultimate Conspiracy Theory, BBC News Online MagaziNe, June 3, 2004, http://news.bbc.co.uk/1/hi/magazine/3773019.stm.

15. Trilateral Commission, About the Organization, http://www.trilateral.org/about.htm (last visited Apr. 3, 2008).

16. World Economic Forum, About the World Economic For um, http://www.weforum.org/en/ about/index.htm (last visited Apr. 3, 2008).

17. The contemporary shifting influences in global governance towards Asian countries have been described by Ahearne and others as highlighted by the recent redistribution of IMF voting rights in favor of China, Korea, Mexico and Turkey at the expense of European votes. See Alan A hearne et al., Global Governance: An Agenda for Europe (Bruegel Policy Brief, Dec. 2006), available at http://www.bruegel.org/Public/Publication_detail.php? ID =1169\&publicationID = 1267 .

18. See Leslie Sklair, Sociology of the Global System, in The Globalization Reader 70, 70 (Franklin J. Lechner \& John Boli eds., 2d ed. 2003). 
based on a simplistic model of the market economy, the competitive equilibrium model, in which Adam Smith's invisible hand works, and works perfectly. Because in this model there is no need for government-that is, free, unfettered, "liberal" markets work perfectly-the Washington Consensus policies are sometimes referred to as "neo-liberal," based on "market fundamentalism," a resuscitation of the laissez-faire policies that were popular in some circles in the nineteenth century. ${ }^{19}$

However, there is now a "Post-Washington Consensus [that] has added civil society, social capital, capacity building, governance, transparency, a new international economic architecture, institution building, and safety nets. ${ }^{.20}$ But this new consensus has also been described as "the systematic transformation of social relations and institutions in the developing world, in order to generalise and facilitate proletarianization and capitalist accumulation on a global scale, and build specifically capitalist hegemony through the promotion of legitimating schemes of community participation and [country] ownership."21

The role and impact on women of this new phenomenon is often ignored. The 2000 Report to the United Nations Committee on Economic, Social, and Cultural Rights (UNCESCR) on globalization examined the institutional framework that has been developed to pursue the essential goals of globalization and the related questions of equality and nondiscrimination with a particular focus on the effects of globalization on women. ${ }^{22}$ In 1998 the UNCESCR pointed out that:

Women have entered the workforce in large numbers in States that have embraced liberal economic policies. One United Nations survey concludes that '[i]t is by now considered a stylized fact that industrialization in the context of globalization is as much female-led as it is export led.' The overall economic activity rate of women for the age group 20-54 approached 70 per cent in 1996. The highest absorption of women has been witnessed in the export-oriented industrial sector

19. Joseph E. Stiglitz, Globalization and Its Discontents 74 (2003). See generally Joseph E. Stiglitz, Making Globalization Work (2007).

20. See Richard Higgott, Contested Globalization: The Changing Context and Normative Challenges, 26 Rev. of INT'L. Stud. 131, 139-140 (2000).

21. Paul Cammack, What the World Bank Means by Poverty Reduction, and Why it Matters, 9 New Pol. Econ. 189, 190 (2004).

22. Preliminary Report, supra note 4, at If 3. 
.... Thus, according to the Women's Environment and Development Organization (WEDO) women bear the disproportionate weight of the constraints introduced under the yoke of globalization. ${ }^{23}$

Jeffrey Sachs points out in The End of Poverty that the effect of globalized industrial development on Bangladesh has been a 66 percent drop in infant mortality in thirty years, ${ }^{24}$ and a reduction in numbers in extreme poverty in India and China, respectively, by two and three hundred million people since $1990 .{ }^{25}$ Significantly, he claims that the women working in the sweatshops "already have a foothold in the modern economy that is a critical, measurable step up from the villages of Malawi." ${ }^{26}$ Perhaps globalization represents, therefore, more than anything else, a greater proletarianization of women's work worldwide. ${ }^{27}$

\section{B. Globalization of Homelessness}

In relation to globalization and housing, Miloon Kothari, the U.N. Special Rapporteur on adequate housing, has pointed out that the reality is bleak:

While the majority of the world's population lives in some form of dwelling, roughly one half of the world's population does not enjoy the full spectrum of entitlements necessary for housing to be considered adequate. United Nations estimates indicate that approximately 100 million people worldwide are without a place to live. Over 1 billion people are inadequately housed. ${ }^{28}$

While global economic integration is creating new wealth, the number of homeless or precariously sheltered persons continues to grow. For the homeless and the poor, the benefits of globalization have been insignificant at best; some see the IMF and World Bank as the two institutions responsible for the globalization of poverty. ${ }^{29}$

\section{Id. \31.}

24. Jeffrey Sachs, The End of Poverty: Economic Possibilities for Our Time 10 (2005).

25. Id. at 355 .

26. Id. at 11 .

27. In relation to housing rights and women, see the study by the Special Rapporteur, Miloon Kothari, on Women and Adequate Housing, UN Doc. E/CN.4/2005/43.

28. Adequate Housing, supra note 5, at 2.

29. See generally Michel Chossudovsky, The Globalization of Poverty: Impacts of the IMF and World Bank Reforms (1997). 
Findings from the UN-Habitat Global Urban Indicators Database reveal that there is a wide gap between income groups, within countries and across countries in terms of the availability, affordability and habitability of housing and access to utilities and essential services, ultimately resulting in an increase in the number of people in inadequate housing and living conditions. In Peru, reforms sponsored by the International Monetary Fund's structural adjustment programme in 1990 drove up rates of inflation and contributed to a significant decline in the real minimum wage. It is estimated that the population of street-dwelling poor rose to 5 million. ${ }^{30}$

In terms of housing and other socio-economic human rights, the U.N. Committee on Economic, Social and Cultural Rights (UNCESCR) pointed out in 1998 that:

The negative impact of globalization-especially on vulnerable sections of the community-results in the violation of a plethora of rights guaranteed by the Covenants. In particular, the enjoyment of fundamental aspects of the right to life, freedom from cruel, inhuman or degrading treatment ... [and] the right to an adequate standard of living (including the right to adequate food, clothing and housing) ... have been severely impaired. Developing states are, more often than not, compelled by the dynamics of globalization to take measures that negatively impact on the enjoyment of those rights. The result is that states cannot fulfil their international human rights obligations, even if they are desirous of improving the human rights situation in their countries. The critical question is the following: Can international economic forces that are engineered by both state and private actors be unleashed on humanity in a manner that ignores international human rights law? ?1 $^{31}$

In 2005, the answer to this searching question was given by the U.N. Special Rapporteur on Housing.

Based on the current trajectory, the future seems bleak for the world's most vulnerable populations. More than 100 million people 
in the world's poorest countries are projected to be living below the basic subsistence level of a dollar a day by 2015, caught in the poverty trap that is associated with economic globalization's dark side. An in-depth study on the world's 49 least developed countries rejects claims that globalization is beneficial for the poor, arguing that the international trade and economic system is part of the problem, not the solution. Accordingly, the current form of globalization is tightening rather than loosening the international poverty trap. As markets become more entwined, the world economy is becoming increasingly polarized and the least developed countries, particularly their poorest people, are being left behind. It is important to note that this also applies to high-income industrialized countries, where a growing number of households are living below the poverty line due to increasing unemployment, and in many cases a simultaneous decrease of social welfare and social security as a result of reduced public investments. ${ }^{32}$

Even in Europe, the Fédération Européenne d'Associations Nationales Travaillant avec les Sans-Abri (the European Federation of National Organisations Working with the Homeless, FEANTSA) has raised the issue of the contemporary crisis of housing:

This shockingly inadequate housing is symptomatic of the underlying problem of housing affordability that is growing across Europe. Quite simply, there is no housing available for the limited financial resources that poor and vulnerable groups have at their disposal. This problem of affordability affects all actors - naturally poor people are the most visible victims - but middle-income groups are increasingly affected and NGOs and the state are also feeling the repercussions....

For very poor people the terrible pressure of the housing market increasingly leads to social exclusion and, in some cases, to a situation of social emergency, where people find themselves without resources, reduced to sleeping in the street.... Increasing numbers of people sleep in doorways, squats, abandoned buildings and other 
places not meant for habitation. What is more, the profile of these people is changing. They are not only the middle aged, often alcoholic men who are associated with rough sleeping and who are often held to be to blame for their own situation. Nowadays, it is frequently women, families with children, migrants and young people who find themselves homeless or in a situation of social and housing emergency. The trigger of their plight is usually housing affordability, leading to a spiral of exclusion, affecting health, $\mathrm{cm}$ ployment options, education of children etc. Housing exclusion due to lack of affordable housing also creates an extreme vulnerability to exploitation. It has led to a new and frightening form of housing exploitation: mattress rental by so-called 'sleep dealers.' In effect, exploitative landlords rent out mattresses in overcrowded conditions for eight hour shifts at exorbitant prices. It is migrant workers that are the main victims of such practices. ${ }^{33}$

\section{Globalization from Below}

The "Battle of Seattle" has been described as the first political crisis of globalization. ${ }^{34}$ The clash was between an economistic view of the future and a normative one. "In effect, it was not globalization that was at issue, but what kind of globalization." 35 "Globalization-from-below" is posited as a counter movement to the hegemony of the Washington Consensus. It involves popular participation at local levels, the building of civil societies, global citizenship, and the enhancement of non-governmental organizations as part of the strengthening over time of the institutional forms and activities associated with global civil society. ${ }^{36}$ This globalization from below has been profiled as a world composed of several plural worlds.

Certainly, they have a common enemy: the hegemonic globalisation and its agents, even when the choices they outline might present different shapes. They are integrated by peasants' and students'

33. Press Release, European Federation of National Organisations Working with Homeless (Aug. 2005), avuilable at http://www.feantsa.org/code/en/pg.asp? Page $=558$.

34. Richard Falk, Interpreting the Interaction of Global Markets and Human Rights, in GLobalization and Human Rights 61, 61 (Alison Brysk ed., 2002).

35. Id.

36. See generally Nigel Dower \& John Williams, Global Citizenship: A Critical Reader (2002). 
organisations, human rights leagues, ecologists' and feminists' associations, movements against war, groups for reclamation of equal access to earth and drinkable water ....37

Globalization-from-below (often using the Internet), or subaltern globalization, is manifested in such events as the World Social Forum, ${ }^{38}$ the practice of participatory budgeting in Porto Alegre, Brazil, and other social movements and innovative approaches. ${ }^{39}$ Indeed, Orly Lobel indicates that "the State itself, lacking control vis-à-vis grander, more obscure and dispersed forces, is merely one out of many actors and vehicles for action. [It is in] Boaventura de Sousa Santos' terms 'the newest social movement."'10

Globalization can therefore be seen as a phenomenon promoted by powerful forces with potentially enormous consequences for housing law, policy, and rights.

\section{Some Impacts of Globalization on Housing}

While globalization or global neoliberalism is multifarious, many of its elements are having a significant impact on housing systems, and consequently on housing law, policy, and especially housing rights. The growth and power of globalized corporations involved in housing; the globalization of property rights, housing finance markets, and the promotion of owner-occupation; globalized real estate investment in housing; the reordering of cities and slums; new roles for the state in relation to housing; and the effect of globalized migrants and refugees all present new and undetermined challenges. Of course, the development of technology, new building materials, and new methods of construction have also brought important changes.

37. Gerardo Pisarello et al., Derechos Sociales Y Globalización: A Modo De Introducción [Society Rights and Globalization: By Way of Introduction] 11 (Observatori DESC 2003) (translated by author).

38. See Teivo Teivainen, The World Social Forum and Global Democratisation: Learning from Porto Alegre, 23 Thiro World Q. 621 (2002).

39. See Law and Globalization From Below: Towards a Cosmopolitan Legality (Boaventura de Sousa \& César A. Rodríguez-Garavito eds., 2005).

40. Orly Lobel, The Paradox of Extra-Legal Activism: Critical Legal Consciousness and Transformative Politics, 120 Harv. L. Rev. 937, 966 (2007). 


\section{A. Global Corporations and Housing}

The diverse elements of housing systems, from building materials, the production of homes, financing, management, exchange, and the creation of contemporary living environments have spawned and nurtured many global corporations. Among the global corporations comprising the Fortune 500 list in $2006,{ }^{11}$ six corporations specialized in building materials and glass, ${ }^{42}$ with a further eleven specializing in engineering and construction. ${ }^{43}$ Those corporations specializing in house-building included Lennar, D.R. Horton, Centex, KB Home, Toll Brothers, Hovnanian Enterprises, NVR, Beazer Homes USA, MDC Holdings, Ryland Group, Standard Pacific, Meritage Homes, WCI Communities, and William Lyon Homes. There were ten corporations specializing in real estate, including residential real estate. One of these corporations, the RE/MAX Estate Agency, has a global presence with nearly 115,000 agents in more than 65 countries. ${ }^{44}$ Some fifty-one corporations were gas and electric utility companies, many having a major impact on housing. Seven of the top five hundred corporations were listed as specializing in furniture for homes. Some thirty corporations were commercial banks, financing house purchase among other activities, led by Citigroup, now located in ninety-eight countries. ${ }^{45}$ Clearly, globalized housing corporations have arrived, with their CEOs attending meetings of the Bilderburg Group and other international global organizations. Of course, much housing construction is still traditionally undertaken by local builders with good political connections, local knowledge of market conditions, supplies, and opportunitics for development.

\section{B. The Globalization of Property Rights in Housing Systems}

A significant development in housing globalization is the preoccupation with property registration systems in land, designed to facilitate markets and housing

41. See Fortune Global 500, available at http://money.cnn.com/magazines/fortune/fortune $500 /$.

42. Owens Corning, USG, Armstrong Holdings, Vulcan Materials, Martin Marietta Materials, and Texas Industries.

43. Fluor, Jacobs Engineering, Emcor Group, Peter Kiewit Sons', URS, Shaw Group, Washington Hill Group, CH2M Hill, Granite Construction, Quanta Services, and Perini.

44. See RE/MAX Real Estate, Corporate Information, http://www.remax.com/inside_remax/ corporate_information/index.aspx (last visited Apr. 3, 2008); see also Century 21, Company Profile, http://www.century21.com/content/learn_c21System_companyProfile.aspx (last visited May 9, 2008) (real estate agents with 8,400 franchised and independent offices in 58 countries).

45. See Citigroup, About Citi, http://www.citigroup.com/citigroup/about/index.htm (last visited Apr. 3, 2008). 
finance systems. Contemporary writers on global development, such as Hernando De Soto, ${ }^{46}$ claim that one of the principal reasons for the underdevelopment of nations is the absence of a property registration system to facilitate mortgage lending, consequently prohibiting the development of personal capital and equity growth in land and housing. ${ }^{47}$ Indeed, recent research by the Organisation for Economic Co-operation and Development (OECD) confirms the existence of significant housing wealth effects on consumption in the United States, United Kingdom, Canada, the Netherlands, and Australia as a result of increasing housing equity held in owner-occupied homes. ${ }^{48}$

Shlomo Angel highlights that the development and facilitation of housing markets requires legal instruments and state involvement to create five essential elements: a property rights regime, a housing finance regime, a residential infrastructure regime, a regulatory regime, and a housing subsidies/public housing regime. ${ }^{49}$
A functional and effective property rights regime must evolve a set of transparent, predictable, non-discriminatory and stable rules that pre- serve the rights of individuals to use, invest, maintain, rent, mortgage and sell their land and housing properties without hindrance and with the full protection against arbitrary action by the authorities. ${ }^{50}$

\footnotetext{
46. Hernando De Soto, The Mystery of Capital: Why Capitalism Triumphs in the West and Fails Everywhere Else 6 (2000).

47. Id. But see Land Rights and Innovation: Improving Tenure Security For the Urban Poor (Geoffrey Payne ed., 2002) (challenging De Soto's views on grounds of the cost and pace of formal titling, the existence of a continuum of tenure categories, and the suspicion of the poor toward banks). See generally Christopher Woodruff, Review of de Soto's "The Mystery of Capital," 39 J. Econ. Lit. 1215, 1218 (2001) (suggesting the costs of adjudicating claims may abrogate the gains from titling); Joe Flood, Secure Tenure: Global Definition and Measurement 6 (Paper to European Network of Housing Researchers Conference, Vienna, 2002) (explaining that property and tenure rights in Europe grew from feudal and bourgeois concerns and mobilizing the capital of the middle class and not from any desire to tap the capital controlled by the poor).

48. Pietro Catte et al., Housing Markets, Wealth and the Business Cycle 11-16 (OECD Econ. Dept., Working Papers No. 394, 2004).

49. Shlomo Angel, Housing Policy Matters: A Global Analysis 19 (2000). This article does not seek to endorse the World Bank approach which has been widely criticized for its failure to protect human rights and to prevent poverty, inequality and oppression in its promotion of market approaches. See Bretton Woods Project, Home Page, http://www.brettonwoodsproject.org/ (last visited Apr. 3, 2008). The Property Rights Index was developed internationally by the World Bank in 1990, combining the Freedom of Exchange Index and the Land Registration Index.

50. See ANcel, supra note 49, at 95.
} 
The World Bank stresses that clear and enforceable legally defined property rights provide the necessary infrastructure for the global economy. ${ }^{51}$ Indeed, the export of U.S. and European legal systems and property law have played a crucial part in the globalization epoch, providing the means of legitimation for patenting, control, appropriation, and commodification of physical and human resources worldwide. ${ }^{52}$ Stefan Andreasson claims that the contemporary international vigor to create property rights in land and housing can be viewed as merely one step beyond the former colonial processes of dispossession of property by force. ${ }^{53}$ Such appropriation and commodification, often through appalling means, was once justified in the conception of private property by Lockean writings and later expounded by liberal thinkers. ${ }^{54}$

There is an important link between the essentially liberal project of primitive and capitalist accumulation and liberal thinkers, from John Locke to Friedrich Hayek, and the ideology and policy of international financial institutions managing the global economy today - the International Monetary Fund (IMF), the World Bank and the World Trade Organisation (WTO)..$^{55}$

51. From Plan to Market: World Development Report 1996 at 48 (World Bank 1996); The State in a Changing World: World Development Report 1997 at 32 (World Bank 1997).

52. See generally MARx, supra note 10 (claiming that the formal legal rights of equality, freedom of contract, and property rights were in fact mere masks for what was, in reality, a system of exploitation of wage labor, and which generated the commodification of labor itself and ultimately all human needs. The alienation of people from the products of their labor (in the form of the surplus value appropriated by the capitalists), from each other, and from the society in which they took part, had created a new type of society. On the one hand, capitalism had freed people from the religious and superstitious controls of primitive societies, had broken the fetters of feudal society and permitted scientific development and people's awareness. On the other hand, it had created alienation, generated awesome poverty and living conditions, and a growing immiseration of the poor, alongside consistent and powerful accumulation of wealth, protected by State-enforced property rights. These property rights were the same as had previously been asserted against monarchs and feudal states by the rising bourgeoisie social movements of the French and American revolutions).

53. Stefan Andreasson, Stand and Deliver: Private Property and the Politics of Global Dispossession, 54 Pol. Stud. 3, 3-22 (2006).

54. Kevin Cahill, Who Owns the World: The Hidden Facts Behind Landownership 33 (2006) (claiming that thirty-five monarchies, including the papacy, rule over one-third of the world's surface. Monarchical rule exists in fifty-one States and thirty-six colonies and dependencies of the world's 197 States); id. at 48 (pointing out that instead of redressing these disparities in land ownership, human rights instruments, such as the UN Universal Declaration on Human Rights and the European Convention on Human Rights, have actually consolidated this unequal ownership by requiring compensation to be paid on confiscation or redistribution).

55. Andreasson, supra note 53, at 4. 
Clearly, enforceable property rights in land and housing are required for international finance corporations to extend their operations into the potentially enormous markets of the future. However, some are skeptical as to the benefits. "This extension of property rights- both in terms of that to which they apply and the range within which they are applied-further erodes possibilities for broadbased development globally as well as any hope of mitigating increasing global polarisation of wealth and knowledge." 56

The relentless ideological drive worldwide toward privatization of public or social housing and the forced creation of owner-occupation leading to a "market," but without a proper registration system, has proven to be ill-judged in the Russian Federation and other countries. ${ }^{57}$ The registration of titles as the basis for a functioning housing market has created many side effects, chiefly, the exploitation of those without education and awareness of law. Of course, it has been pointed out that the major impacts of these policies have been to destroy communal land and housing management systems, but also to promote neo-liberal approaches, which at the same time undercut the profitability and viability of family-scale agriculture..$^{58}$ Indeed, the result can be increased landlessness and destitution through mass sell-offs by impoverished new landowners, forced to migrate to cities, leaving a reconcentration in the hands of large landowners.

However, De Soto's approach was endorsed by the World Bank in 2006, as its contemporary policies on housing in developing countries have moved further toward market-based approaches. ${ }^{60}$ The Bank's views on appropriate shelter policies "support] most (but certainly not all) of the conjectures made about the use of market-friendly policies." ${ }^{.61}$ However, there is now an acceptance by the Bank

56. Id. at 8 .

57. See U.N. Econ. Comm'n for Europe, Country Profiles on the Housing Sector: Russian Federation 2-3 (2004), available at http://www.unece.org/h/m/prgm/cph/countries/russia/welcome.htm; ECOSOC, Comm. on Housing \& Land Mgmt., Econ. Comm'n for Europe, Draft Programme of Work for 2007-2008, U.N. Doc. ECE/HBP/2006/2 (July 10, 2006).

58. See Peter Rosset, The Good, the Bad and the Ugly: World Bank Land Policies, http://www landaction.org/display.php? article $=177$ (suggesting that it is significant that the World Bank has not provided funding for similar land distribution policies in Zimbabwe and also that the World Bank policy is in fact a ploy to depoliticize land reform, to remove it from the realm of politics into the realm of the market).

59. Thirty Years of World Bank Shelter Lending-What have We Learned? xvi (Robert M. Buckley \& Jerry Kalarickal eds., 2006) [hereinafter Thirty Years of World Bank].

60. See Housing: Enabling Markets to Work 19-20 (World Bank 1993); Land Policies for Growth and Poverty Reduction 80 (World Bank 2003).

61. Robert M. Buckley \& Jerry Kalarickal, Housing Policy in Developing Countries: Conjectures and Refutations, 20 The World Bank Res. Observer 233, 251 (2005). 
that there is no mysterious, straightforward capitalist panacea that can address all the shelter problems faced by low-income families in developing countries. Instead of just providing titles to facilitate land markets, registration and finance systems, it now accepts that it is necessary to incorporate the views of poor people on how to effectively address their concerns. ${ }^{62}$

In Europe, the European Land Information Service (EULIS) is developing systems to provide access to property ownership information across borders, using the Internet. ${ }^{63}$ This is intended to create better conditions for borrowers and lenders within the overall European credit market and the development of a Europeanwide title system. ${ }^{64}$ Of course, title registration is complex and involves a hierarchy of interests and charges over the same property, which are sometimes conflicting. ${ }^{65}$

\section{Globalization and Housing Finance}

The most obvious impact of globalization on housing relates to the global house price bubble, prompting The Economist to launch its global house-price indices in 2002, covering twenty countries. The total value of residential property in developed economies increased by an estimated $\$ 20$ trillion to over $\$ 60$ trillion between 2000 and $2003 .{ }^{66}$ Calculations by The Economist suggest that house prices have hit record levels in relation to incomes in the United States, Australia, Britain, France, Ireland, the Netherlands, New Zealand, and Spain. This global housing boom is unusual in its "strength, duration and ubiquity."67

In this domain of highly priced housing markets, purchasing power, or (in reality) access to housing finance, has largely displaced any notions of public entitlements or legal rights as the key to housing access. Housing finance availability

62. Id. at 249 .

63. In 2008, the Danish registration system will become the first fully electronic land registration system in the world. See European Mortgage Federation, Mortgage Info. Special Issue-October 2007, available at http://www.hypo.org/content/default.asp? PageID $=218$.

64. Infoland, https://www.infoland.no/wps/infoland/\#_top (last visited Apr. 3, 2008).

65. Forum Group on Mortgage Credit Markets, European Commission, The Integration of the EU Mortgage: Credir Markets (2004), hitp://europa.eu.int/comm/internal_market/ finservices-retail/docs/home-loans/exsum_en.pdf (recommending that all charges affecting real estate should be registered in a Public Register in order to be binding on and take effect against third parties, regardless of their nature, and registered charges on real property in relation to the same estate should rank in the order of priority disclosed in the Public Register); see also JeanBernard Wurm, How US-Style Title Insurance is Transforming Risk Management in European Real Estate Markets, Housing Fin. Int'L 16, 16-19 (2006).

66. Flimsy Foundations: The Global Housing Market, The Economist, Dec. 11, 2004, at 71.

67. Id. at 72 . 
depends on developed finance markets, on state interest rate and macro-credit policies, as well as individual criteria for housing loans. ${ }^{63}$ Increasingly, these factors are susceptible to global forces. "The capacity of capital to become 'footloose' and for both manufacturing and service activities to re-locate in search of greater profitability creates, in principle, unpredictability and uncertainty for states, institutions, markets and households with respect to, for example, the permanence of employment or the availability of investment resources (including those for housing) or the withdrawal of production." ${ }^{\prime 9}$ This is better known as the "risk society," described by Giddens and others, where individuals are forced to respond to greater economic risks in their lives. ${ }^{70}$ Globalization has been associated with increasing wage inequality and consequent stratification of housing tenure in market housing systems. Lending policies which discriminate against particular groups or individuals, such as nomads, minorities, Roma, and women, are seldom recognized as such, while these policies clearly violate housing rights in the housing finance system. The development of sub-prime mortgage markets (often by major global lenders such as Citigroup), which charge higher-than-normal interest rates to facilitate those without the standardized credit requirements, or without a deposit for house purchase, is a growing feature of housing finance. ${ }^{71}$ Indeed, it is the subprime mortgage borrowers at risk from unemployment, illness, interest rate increases, falling prices, or other setbacks, who are most likely to become homeless. Housing rights have a special relevance for this category of homeowners.

Technological developments in housing finance have been dramatic. Electronic and Internet systems have revolutionized the concentration and outsourcing of mortgage brokering and servicing, creating new and more sophisticated services and products, credit scoring, and automated underwriting, as well as

68. See Housing Finance in Transitional Economies (OECD 2002).

69. Globalisation and Home Ownership: Experiences in Eight Member States of the EuRopean UNion 2 (John Doling \& Janet Ford eds., 2003).

70. Anthony Giddens, Modernity and Self Identity: Self and Society in the Late ModERN Age 28 (1991).

71. See Committee on the Global Financial System, Housing Finance in the Global Financial Market 17 (Bank for International Settlements, CGFS Papers No 26.2006), available at http:// www.bis.org/publ/cgfs26.htm (pointing out that sub-prime lending, particularly in the United States, has grown rapidly in a period in which an increasing number of borrowers have taken out interest-only or variable rate loans (including some with negative amortization options) and in which house prices have risen. It notes that risk models of financial institutions have in many countries not been tested in a downturn scenario featuring a rapid increase in interest rates and a strong decline in house prices. Thus, there may be a risk that lenders are underestimating households' probability and severity of default). 
standardization of documentation and legal structures. ${ }^{72}$ Of course, the integration of mortgage providers is a clear response to global pressures of economies of scale, but there remain significant barriers, especially at the European level. ${ }^{73}$

The World Bank has recently described the speed at which market-based housing finance has spread around the world. "Since about 2000, the world changed from one in which most of the world's population did not have access to mortgage finance to one in which most of the world's population now lives in countries with a market-based mortgage finance system with generally affordable terms. ${ }^{\prime 74}$ Yet, the Bank acknowledges that "[w]hile market-based housing finance is now available to most middle-income people in the world it is still not available in most countries or for the poorest people." ${ }^{\text {T5 }}$ Many people in informal housing situations, such as house renters or squatters, are unable to access housing finance because they have no clear marketable or mortgageable title. ${ }^{76}$ Indeed, the Bank for International Settlements (BIS) points out that housing finance products directed towards households are still to a large extent provided at a regional or local level. ${ }^{77}$

In Europe, financial market liberalization in mortgage markets has been strongly developed, with the abolition of interest rate ceilings, relaxation of credit

72. Id. at 22-23.

73. See Mercer Oliver Wyman, Study of the Financial Integration of European Mortgage Markets 3-7 (2003).

74. Thirty Years of World Bank, supra note 59, at xii.

75. Id.

76. U.N. Centre for Human Settlements, Cities in a Globalizing World: Global Report on Human Settlements 2001 at 77-87 (contrasting the view of housing as a right with housing as a function of ability-to-pay or purchase as a commodity in housing markets; nevertheless, it outlines how globalization impacts housing finance).

77. Committee on the Global Financial System, supra note 71, at 23:

However, financial liberalisation has unleashed comperitive pressures from global providers, which have forced national and regional players to respond by altering their product offerings, providing better pricing (which requires increased efficiency) and extending the range of services through customisation. At the same time, the liberalisation and resulting globalisation have made capital markets more liquid and efficient, which may have contributed to a shift from a bank-centred system towards a more market-based one. This process is likely to be strengthened further by the implementation of Basel II, which provides a more transparent and market-oriented regulatory framework. At the same time, the implementation of Basel II is expected to lead to a stronger role for rating agencies, in the national as well as the international market for mortgage credit. This trend is likely to be reinforced by the continued growth of secondary mortgage markets, as rating agencies are likely to focus on assessing the credit status of MBSs in order to increase their appeal to international investors. Globalisation of funding may also have been encouraged by the strength of banks' mortgage lending relative to deposits, forcing intermediaries to fund their business via capital markets. 
controls, and the ending of restrictions on entry into mortgage markets. ${ }^{78}$ As of 2005, there were 65.1 trillion residential mortgage loans outstanding in the European Union, representing 47 percent of EU Gross Domestic Product (GDP). ${ }^{79}$ The size of national mortgage markets, however, varies considerably ranging from $€ 1.4$ trillion in the United Kingdom and $€ 1.2$ trillion in Germany to $€ 1.3$ billion in Slovenia and $€ 1$ billion in Bulgaria. Mortgage debt as a percentage of GDP also varies considerably, representing 97 percent and 94 percent of GDP in the Netherlands and Denmark respectively to 5 percent and 6 percent of GDP in Slovenia and Poland. Mortgage debt to GDP ratios have however risen steadily across almost all European Union countries in recent years, reflecting the higher value of household assets as well as rising numbers of mortgage borrowers. This can be attributed to a range of different factors including increasing residential investment, higher income expectations, falling interest rates and favorable tax treatment for mortgage loans. ${ }^{80}$

Of course, the common European currency-the euro, combined with its interest rate policy vested in the European Central Bank, has impacted housing finance markets, while the European Commission is pushing for greater internal market reforms in this area. ${ }^{81}$ In the United States, some 56 percent of mortgages are securitized, while in Europe, (EU-15) at end-2004, the level of securitization was around 15 percent of all mortgages. ${ }^{82}$

At a macroeconomic level, the use of interest rates and credit controls have become a common response to the global abolition of currency restrictions and the huge flows and casy mobility of capital (over 80 percent of capital is estimated to be part of speculative flows). Greater integration of housing finance markets with general circuits of finance means that "homeowners are increasingly competing for

78. See Michael Ball, RiCS European Housing Review 2005 (2005); European Central Bank, Structural Factors in the EU Housing Markets (2003).

79. European Mortgage Federation, Hypostat 2005: A Review of Europe's Mortgage and Housing Markets 140 (2006).

80. European Central Bank, Structural Factors in the EU Housing Markets 6, 45 (2003). See generally Commission Staff Working Document: Accompanying Document to the White Paper on the Integration of EU Mortgage Credit Markets: Summary of the Impact Assessment, COM (2007) 807 final, SEC (2007) 1683.

81. See Forum Group on Mortgage Credit, supra note 65 (explaining that the European Commission created the Forum Group on Mortgage Credit in 2003 to identify and assess the impact of the barriers to the smooth functioning of the internal market for mortgage credit and make appropriate recommendations to tackle these barriers. One of these recommendations was that the Commission should explore the concept of the Euromortgage, for example by way of a study, to assess its potential to promote EU mortgage credit markets integration).

82. See Committee on the Global Finance System, supra note 71, at 14. 
capital in the same pool as the richest multinational corporations. ${ }^{.83}$ Clapham points out that the removal of regulations on housing finance as part of the general deregulation of finance markets is credited with the house price volatility in Britain in the 1980s. ${ }^{84}$ Similar outcomes for many EU states followed the convergence of currencies into the euro, with a common (and low) interest rate, which took place in the $1990 \mathrm{~s} .{ }^{85}$ Historically low interest rates since 2001 have led to a housing price bubble, encouraging the growth of sub-prime lending to those with poor credit histories or lacking down payments, with many risks to the entire housing valuation system. ${ }^{86}$ The 2001 United Nations Centre for Human Settlements (UNCHS) Report, Cities in a Globalizing World, ${ }^{87}$ pointed out that while globalization has increased the informal economy, the formal sector commercial financial institutions regularly refuse housing credit to people without permanent employment, collateral, or established credit records. Indeed, the biggest investors in low-income housing worldwide are the poor themselves, with contributions from family and friends. ${ }^{88}$

Global finance competes with local private and state bodies for land in the new globally networked cities. This has an enormous impact on subsequent housing costs and affordability of housing, as well as the location and subsidy levels required for social housing. As the UNCHS has pointed out, "Many cities now acknowledge that the current nature of funding flows and investment capital demands an international urban orientation over and above managing local issues. ${ }^{{ }^{\prime 89}}$ States are faced with the outcomes of rising market prices where key workers such as teachers and public servants cannot afford to buy housing. In Europe, political pressures from these organized groups have led to various "affordable" housing schemes to enable access to the market by state subsidies on mortgages, land, or purchase prices. ${ }^{90}$ The

83. See U.N. Centre for Human Settlements, supra note 76, at 78; Terrence McDonough, What Does Long Wave Theory have to Contribute to the Debate on Globalization, 35 Rev. of RAdicaL Pol. ECon. 280, 280-86 (2003).

84. David Clapham, Housing Policy and the Discourse of Globalization, 6 Eur. J. Hous. Po''y 55, 58 (2006).

85. See Clodagh Memery, The Housing System and the Celtic Tiger: The State Response to a Housing Crisis of Affordability and Access, I Eur. J. of Housing PoL'y 79, 89-90 (2001).

86. See Souphala Chomsisengphet \& Anthony Pennington-Cross, The Evolution of the Subprime Mortgage Market, Federal Reserve Bank of St. Louis Review, January/February 2006, at 31.

87. U.N. Centre for Human Settlements, supra note 76, at 77-87.

88. Id.

89. Id. at 4.

90. See Barrie Needham \& George de Kam, Land for Social Housing (CECODHaS 2000), http://www.ru.nl/aspx/download.aspx/download.aspx? File = contents/pages/140643/landfor socialhousing.pdf\&structuur $=$ gap? 20 - 
effect of course, is to buttress the rising markets, and states are drawn into higher and higher levels of subsidies as the prices of starter homes rise with the market.

\section{Globalized Real Estate Investment}

Globalized investment and speculation in real estate and housing is pervasive in all major cities of the world. Even at the European level, where markets are well developed, returns (rental income and capital growth) from residential property investment in 2003 were 11.5 percent in the United Kingdom, 10.9 percent in Denmark, 10.7 percent in Portugal and 9.6 percent in Sweden. ${ }^{91}$

The U.N. Habitat International Coalition has identified a new phenomenon, Real Estate Investment Trusts (REITS), as an emerging part of this development. REITs, originally developed in the United States, are real estate companies listed on the stock exchange.

In France REITs were introduced 2 years ago and this seems to have significant effects on the bubble and giant sales of shares.... In Germany it is estimated that the mid-term potential for privatisations and other sales of real estates to REITs is about 100 billion dollars. This figure probably includes all types of public infrastructure like schools etc. In Honkong [sic] after the introduction of REITs there seems to be a real wave of new speculations with consequences on raising rents. Some articles speak about a new beginning speculation bubble in eastern Asia, stimulated by REITs. ${ }^{92}$

"Similar capitalist groups as in Germany are penetrating markets in Spain, Turkey and elsewhere. In Eastern Asia a new speculation wave is on the run... And nearly everywhere public investment on affordable housing gets reduced. ${ }^{{ }^{9} 3}$

Another trend in this area is what Habitat International Coalition refers to as the "The Global Fundisation of Housing." In Germany and many other Euro-

91. A.D.H. Crook \& Steven Rowley, Opportunity Knocks? Institutional Investaient in the Private Rented Sector in Ireland (2004), http://www.threshold.ie/documents/InvestmentrReportCompleteFINAL.pdf. See also A.D.H. Crook \& P.A. Kemp, Investment Returns in the Private Rented Housing Sector (2002), http://www.bpf.org.uk/pdf/17901/resdoc10194758434200-1.pdf.

92. Knut Unger, The Global Fundisation of Housing-First Sketch and Questions, HA BITAT INT'L Coalition, Jun. 20, 2005, http://www.hic-net.org/articles.asp?PID=267.

93. Knut Unger, Global Fundisation and Mass Privatisation of Housing, Навitat Int'L CoallTron, Oct. 21, 2005, http://www.hic-net.org/articles.asp? PID = 401. 
pean and post-communist countries, housing conditions are faced with the rapid direct globalization of the real estate markets. The intensity and quantity of this process is a new phenomenon and is creating widely undesirable and inequitable outcomes. ${ }^{94}$ International speculative financial capitalists, in particular so called Private Equity Funds, are invading the housing markets by buying huge housing stocks and whole companies from their original owners or shareholders. In recent times, in Germany, nearly half a million flats were sold to international funds. Most of the affected housing stocks are former social housing or company flats, which form significant parts of mass housing in Germany. ${ }^{95}$

Another significant development has been the growth of semi-autonomous "Housing Funds" by states to borrow private finance for housing from the global capital markets to channel to municipal housing and non-profit companies investing in social housing. The Housing Fund in Finland, with its Special Purpose Vehicle based in Ireland, borrows international finance securitized on its social housing with a state guarantee. ${ }^{96}$ In Ireland, the Housing Finance Agency carries out a similar role, ensuring that such capital housing expenditure does not affect state obligations to limit public expenditure in line with the EU Growth and Stability Pact. Other approaches have involved direct borrowing from capital markets by non-state social housing providers in lieu of state loans, such as has occurred in the Netherlands and United Kingdom. ${ }^{97}$

At another level, the development of a housing futures market in the United States represents a truly global development. The Chicago Mercantile Exchange has launched trading in U.S. home prices by allowing investors to trade in housing-price futures based on the median home price in each of 10 U.S. cities. ${ }^{98}$ There is to be

94. See Croatian Tenants: Last Victims of the War, Global Tenant: International Union of Tenants Quarterly Magazine, Sept. 2006, at 6 (describing how the International Union of Tenants has highlighted recent mass evictions in Croatia and many other countries as a result of "development."); see also UNECE Committee of Human Settlements, County Profiles on the Housing Sector, http:// www.unece.org $/ \mathrm{h} / \mathrm{m} / \mathrm{prgm} / \mathrm{cph} / \mathrm{countries} / \mathrm{russia} /$ welcome.htm (discussing Russia's housing reform).

95. See Unger, supra note 92.

96. See Sirpa Tulla, Securitisation and Finance for Social Housing in Finland, 36 URB. Stud. 647-56 (1999) (describing the changes in public finance in Finland).

97. See Hugo Preimus \& Jacqueline Smith, Social Housing Investment: Housing Policy and Finance in the UK and the Netherlands, 1970-1992, 11 J. Hous. Built Ent't 401, 401-19 (1996) (analyzing the changing housing policies and the developing structures of social housing finance); see also AMA Research, Housing Association Market Report UK 2006, http://www.amaresearch.co.uk/ HsgAssoc06c.html.

98. CME Group, SEP/Case-Shiller Home Price Indices Futures and Options: Introductory Guide, http://www.cme.com/files/cmehousing_brochure.pdf (describing the U.S. housing market and its dramatic increase in the last couple of years). 
"Electronic Trading Around the Clock, Around the World." ${ }^{.99}$ The contracts, which are three and six months in duration, are benchmarked against the National Association of Realtors reported Median Sales Price of Existing Single-Family Homes in Chicago, Los Angeles, Miami, New York City, San Diego, and San Francisco.

\section{E. Reordering of Cities and Slums}

Aside from the effects of global capital on housing policies and land prices, globalization is also creating larger, new, physically different city layouts, worldwide. Cities have absorbed nearly two-thirds of the global population explosion since 1950 and are currently growing by a million babies and migrants each week. ${ }^{100}$ The global countryside has reached its maximum population ( 3.2 billion) and will begin to shrink after 2020. As a result, cities will account for all future world population growth, which is expected to peak at about ten billion in 2050. ${ }^{101}$ Ninety-five percent of this increase will occur in the urban areas of developing countries, whose population will double to nearly four billion over the next generation. ${ }^{102}$

A new structural phenomenon has been identified within the world's cities (expected to number 358 with a population of more than one million people by 2015). ${ }^{103}$ A new constellation of globally networked cities, sometimes referred to as the "urban archipelago," is emerging. These cities may have more relations with other cities than with their hinterlands. ${ }^{104}$ However, the housing situation within many of the new cities was adversely affected by World Bank policies, as Davis points out:

99. Id.

100. Mike Davis, Planet of Slums: Urban Involution and Informal Proletariat 26 New Left Rev., Mar./Apr. 2004, at 5. See also Mike Davis, Planet of Slums (2006).

101. Id.

102. Id. at 6.

103. See Naney Yu-pin Chen \& Larry Heligman, Growth of the World's Megalopolises, in MEcACity Growth and the Future 17, 17-32 (Roland J. Fuchs et al. eds., 1994) (describing the concentration of urban population in megalopolises and their growth rate).

104. See U.N. Centre for Human Settlements, supra note 76; Davis, supra note 100, at 8 (pointing out that

Urbanists also speculate about the processes weaving together Third World cities into extraordinary new networks, corridors and hierarchies. For example, the Pearl River (Hong Kong-Guangzhou) and the Yangtze River (Shanghai) deltas, along with the Beijing-Tianjin corridor, are rapidly developing into urban-industrial megalopolises comparable to Tokyo-Osaka, the lower Rhine, or New York-Philadelphia. But this may only be the first stage in the emergence of an even larger structure: 'a continuous urban corridor stretching from Japan/North Korea to West Java.' Shanghai, almost certainly, will then join Tokyo, New York and London as one of the 'world cities' controlling the global web of capital and infor- 
The 1980s, when the IMF and World Bank used the leverage of debt to restructure the economies of most of the Third World, are the years when slums became an implacable future, not just for poor rural migrants, but also for millions of traditional urbanites, displaced or immiserated by the violence of 'adjustment.' ...

... The pain of adjustment should have been followed by the analgesic of globalization. Indeed the 1990s, as Slums wryly notes, were the first decade in which global urban development took place within almost utopian parameters of neoclassical market freedom. ${ }^{105}$

In the globalized cities, there are "mosaics of growing inequality" within the "global archipelago of interconnected city cores." 106 The combination of new information technologies and socio-economic restructuring is reshaping cities and regions and is ushering in new urban forms, with deprivation and poor housing locations also distinguished by under-investment in such technology and services. ${ }^{107}$ "In many developing cities, high quality ICT infrastructures are being packaged through entrepreneurial planning, public subsidies and defensive urban design, into industrial parks for international firms and 'Euro-American' style gated residential enclaves for social and economic elites."108

Of course, the development of these new world cities involves demolitions and evictions:

The [U.N.] Special Rapporteur notes with grave concern that Governments continue the practice of mass evictions in cities as a means of creating 'world-class cities,' lured by the prospect of international investment. Economic globalization has created competition amongst cities that is to the detriment of the poor. The example of

mation flows. The price of this new urban order will be increasing inequality within and between cities of different sizes and specializations.

105. Davis, Planet of Slums, supra note 100, at 18, 22. See also Pietro Garau et al., Task Force on Improving Lives of Slum Dwellers: A Home in a City, UN Millennium Project, available at http:// www.unmillenniumproject.org/reports/tf_slum.htm.

106. U.N. Centre For Human Settlements, supra note 76, at 9, 10.

107. See Manuel Castells, The Informational City: Informational Technology, Economic Restructuring and the Urban-Regional Process (1989) (describing how technology is transforming everyone's lives, including how people portion their time).

108. U.N. Center for Human Settlements, supra note 76, at 11. 
Mumbai, India, is very recent. Between December 2004 and January $2005,80,000$ homes were demolished rendering 300,000 people homeless. For the vast majority of those evicted there was no advance notice, the evictions were violently carried out, and the belongings, including identity cards, of many were damaged or burnt. Those evicted have not been offered alternative accommodation, clearly exacerbating the situation of homelessness in Mumbai. The Chief Minister explained these brutal demolitions as the only way to create a "world-class" city in the future. ${ }^{109}$

It is significant that the U.N. Millennium Development Goals includes the aim of achieving "significant improvement in the lives of at least 100 million slum dwellers by the year 2010."110

Don Mitchell points out that the right to the city manifests itself as a superior form of rights - a right to freedom, to individualization in socialization, to habitat, and to inhabit." Indeed "the right to inhabit implies a right to housing. ... Simply guaranteeing the right to housing may not be sufficient to guarantecing a right to the city, although it is a necessary step toward guaranteeing that right." ${ }^{\prime 2}$ The right to housing is one form of appropriation of the city and very different from a right to property. ${ }^{113}$ Property rights are "an embodied alienation backed up by violence" and are necessarily exclusive, i.e., "possession of a property right allows its possessor to exclude unwanted people from access."114 This act of expulsion frequently involves the power of the state. ${ }^{115}$ This important distinction between property rights and housing rights, which accepts some commonalities on the one hand, but which delves into deeper distinctions on the other, is valuable.

109. Adequate Housing, supra note 5. For more examples of forced evictions, see also Demolished: Forced Evictions and the Tenants' Rights Movement in China (Human Rights Watch 2004) available at http://hrw.org/reports/2004/china0304/.

110. The United Nations Millennium Declaration recognizes the dire circumstances of the world's urban poor. It articulates the commitment of Member States to improve the lives of at least 100 million slum dwellers by the year 2020. UN Millennium Project, Goals, Targets and Indicators, http://www.unmillenniumproject.org/goals/gti.htm (last visited May 30, 2008). As large as 100 million may seem, however, it is only ten percent of the present worldwide slum population, which, left unchecked, will multiply threefold to three billion by the year 2050. Id.

111. Don Mitchell, The Right to The City: Social Justice and The Fight for Public Space 18 (2003).

112. Id. at 19 .

113. Id.

114. Id.

115. Id. at 20. 


\section{F. A Minimal State and Privatization}

Globalization is underpinning the pull of the market in terms of international finance, pressure on space, the reordering of major cities, and in the ideology of the market gaining more and more impact in housing law and policy arenas. Susan Strange points out that there are many reasons for the decline of state power in the era of globalization; among these are technology, through which transfers of information and resources can take place in seconds, and the power of international finance. ${ }^{116}$ George Soros and others have pointed out that the role of the modern state, at the behest of the World Bank, international corporations, and the OECD, involves reducing public services and taxation on profits, although consumption taxes and service charges are increased. ${ }^{117}$ The welfare state is under siege even where it traditionally has been defended, and governments have had to shift the tax burden primarily onto wage incomes and consumer spending. ${ }^{118}$ "The requirements of attracting international capital take precedence over the fulfilment of other social objectives." 19 The conflicting forces between investment capital needed for long term investment with international, unfettered, high-turnover financial capital creates major problems for the management of national economies and state policies. The growth of the neo-liberal model of the globalized state, acting as a minimalist direct service provider, but increasingly and effectively as a powerful controller in the social and workplace spheres, has important consequences for housing law, policy, and rights.

Gavin W. Anderson, in his examination of constitutional rights and globalization, points out that "globalization is effecting a shift of authority from the state to the actors and institutions of the global economy."120 He claims that one of its dominant features was to

116. See Susan Strange, The Declining Authority of States, in The Global Transformations READER, supra note 3, at 127.

117. George Soros, The Bubble of American Supremacy 83 (2004).

118. See Fritz Scharpf, Globalisation and the Political Economy of Capitalist Democracies, in THE Global Transformations Reader, supra note 3, at 370; Stuart Hall, Cosmopolitan Promises, Multicultural Realities, in Divided Citıes 20 (Richard Scholar ed., 2006). Hall points out that the forces of globalization have partly caused and greatly exacerbated the social and physical condition of slum dwellers. Dominant 'neo-liberal' economic doctrines have explicitly demanded an increase in inequality, including the reduction of all government welfare spending, the privatization of everything that the state controlled, the reform of regulation, and the removal of planning restrictions.

119. Soros, supra note 117 , at 84.

120. Gavin W. Anderson, Constitutional Rights after Globalization 18 (2005). 
supplant Keynesian ideas based on the imperative of state intervention with neo-classical cconomic ideas of the minimal state and the deregulated market. Having developed first in the UK and US in the 1980s, neo-liberal policies such as fiscal constraint, free trade, reduced welfare spending and lower taxation, were soon endorsed by governments across the industrialised world, in the transitional economies of Latin America and Central and Eastern Europe, and also in the developing world. Accordingly, by the end of the 1990s, one could identify a worldwide shift 'away from an emphasis on state economic management and service provision, to an ethos of "privatism" in the provisioning and regulation of social and economic life. ${ }^{121}$

Joe Doherty and others at the FEANTSA Observatory point out that globalization at a general level

refers to the tendency for economies and national political systems to become integrated on a global scale and is closely aligned with a neoliberal ideology which champions privatisation and deregulation of the market.... Politically it is associated with the weakening of nation states, involving a 'hollowing out' of state activities and responsibilities, resulting in an apparent decline in political and social autonomy and freedom of action. The hollowing out of the state envisages the divesting of state responsibilities 'upwards' to supra-national organisations (such as the EU), the 'downward' transfer of responsibilities to local government and quasi-state organization, and the dispersion 'outwards' to non-state agencies such as NGOs and the voluntary sector, as well as to private, for-profit enterprises. ${ }^{122}$

The changed and market-oriented role of the state is reflected in housing law and policy in Europe. Mark Kleinman points out that in recent times, housing policy and legislation among almost all countries, including many hitherto largescale state providers, has adopted a bifurcated approach. ${ }^{123}$ Both law and policy

121. Id. at 19-20.

122. See Joe Doherty et al., The Changing Role of the State: State Intervention in Welfare and Housing, FEANTSA 3 (2003).

123. See Mark Kleinman et al., Western European Housing Policies: Convergence or Collapse?, in European Integration and Housing Policy 242 (Mark Kleinman et al. eds., 1998). 
have developed along two paths, which appear to diverge further over time. The primary policy consideration is to facilitate effective market operation, ensuring the exchange of housing, land planning use, access to mortgage finance, sustainable equity, etc. The other part of housing law and policy "relates to the circumstances of the disadvantaged, who are badly housed or homeless, whose prospects of future betterment are uncertain, and whose residential segregation, in many cases, compounds social and economic inequality... 'Housing policy,' as defined in this narrow way is thus mainly concerned with social housing (including its privatisation)."124

On the other hand, the maintenance of owner-occupation as a route to social stability and the normalization of property ownership have become the predominant force in housing policy and law.

Despite the rhetoric about the fight against social exclusion, the reality is that the European political economy is now founded in practice on the acceptance at a more or less permanent level, of a continuing divide between the haves and the have-nots in each country. In housing policy, this underlying belief finds expression in the retreat of national governments from responsibility for achieving more equal outcomes. As the divide grows, policy bifurcates between, on the one hand, measures to maintain market stability for the majority, either in terms of mass owner-occupation or a more balanced private renting/owner-occupation split, and, on the other hand, measures to alleviate some of the worst excesses for the poor, while transferring responsibility from national to local, or even community level. ${ }^{125}$

However, a FEANTSA Report in 2005 shows that while the role of the state in the housing markets of Europe has changed, the nature of that change varies from country to country. ${ }^{126}$

Where states were once 'providers' they now increasingly adopt the role of 'enablers', where they had little history of involvement, their new roles take on a demonstrable 'support the market' function.

124. Id. at 242-43.

125. Id. at 250.

126. Joe Doherty et al., The Changing Role of the State: Welfare Delivery in the Neo-liberal Era, FEANTSA (Brussels 2005). 
This 'surrender' of housing to the market (with and without the intervention of civil society organisations) is well illustrated in the declining and changing role of social housing provision....

... [T]] he problems of curtailed supply have been compounded by the increasing commercialisation of housing associations and housing companies and their consequent adoption of financial 'riskavoidance' strategies which have the effect of drawing social housing away from a focus on the most deprived and at-risk households; the vetting of tenants for 'reliability' and the use of eviction orders are symptomatic of this process. The emergence and expansion of 'innovative' schemes such as 'shared' and 'low cost' home ownershipall invariably involving some private market 'partnership'-provide only a limited alternative to social housing for those with some equity to invest, and no alternative to the most vulnerable...

... [T]he targeting of welfare and the extension of means-testing for access to benefits further marginalise and make access to affordable and adequate housing for some vulnerable households more difficult. In the polarisation of Europe between the 'included' and the 'excluded,' access to affordable and adequate housing is critical. ${ }^{127}$

\section{G. The Rise of "Governance," Networks, and New Patterns of Law}

The creation of the IMF and World Bank exerted influence beyond economic arenas, defining new roles for the state and promoting "governance." 128 This concept has been traced to the Bretton Woods conference and the creation of a new and different approach to the state, law, and democracy from previous traditional and classical democratic principles. ${ }^{129}$ Santos points out that a report by the Trilat-

127. Id. at $6,8,11$.

128. For an account of the sinister use of the World Bank by the U.S. in the Cold War and in funding anti-communist actions in the Third World, see Balakrishnan Rajagopal, From Resistance to Renewal: The Third World, Social Movements, and the Expansion of International Institutions, 41 Harv. Int'L L.J. 529 (2000).

129. See Jeanne M. Woods \& Hope Lewis, Human Rights and the Global Marketplace: Economic, Social and Cultural Dimensions 350 (2005). 
eral Commission in $1975^{130}$ on democracies helped to pave the way for a shift "from legitimacy to governability; from governability to governance." 31 This was further advanced by the World Bank in $19944^{132}$ with its policies of shifting responsibility for the provision of social goods from the state to the market.

"Governance" describes a hybridity of private and public law and institutions, less distinction between formality and informality, and an overall approach within a state in a given area that is oriented towards efficiency and output. In this framework, although based on constitutional and other law, "[l] egality is not an expression of democratic self-determination and liberal respect for individual rights," but rather an instrument for achieving certain (economic) aims. ${ }^{133}$ Governance involves the state and private actors, such as corporations and NGOs, working together. The development of policies and "soft law" measures takes the place of traditional government, which was based on parliamentary debate, legislation, and legal regulation. There is a shift from legal regulation to effective self-regulation for corporations, as a result of the speed and complexity of modern investment, production, and exchange, and to the weak role of states with the presumed need for "expert" specialist monitoring and "enforcement" agencies.

This process is reflected in the more recent shift within the European Union from lawmaking through directives and regulations to "governance" through new methods, such as the Common Objectives, Open Method of Coordination, National Action Plans, etc., in such areas as employment policy, health policy, and social policy. ${ }^{134}$ Significantly, large corporations are also taking part in consulta-

130. Michael Crozier et al., The Crisis of Democracy: Report on the Governability of Democracies to the Trilateral Commission (1975).

131. Boaventura de Sousa Santos, Beyond Neoliberal Governance: the World Social Forum as Subaltern Cosmopolitan Politics and Legality, in LaW and Globalization from Below, supra note 39, at 35.

132. Christoph Mollers, European Governance: Meaning and Value of a Concept, 43 Соммом Мкт. L. Rev. 313, 314 (2006).

133. Id. at 318.

134. See Padraic Kenna, Housing Rights and Human Rights (2005); Susana Borras \& Kerstin Jacobsson, The Open Method of Co-Ordination and New Governance Patterns, 11 J. Eur. Pub. Pou'y 185 (2004); Grainne De Burca, The Constitutional Challenge of New Governance in the European Union, 28 Eur. L. Rev. 814 (2003); Joanne Scott \& David M. Trubek, Mind the Gap: Law and New Approaches to Governance in the European Union, 8 Eur. L. J. 1, 2-5 (2002); Caroline de la Porte \& Philippe Pochet, The OMC Intertwined with the Debates on Governance, Democracy and Social Europe, Report Prepared for the Belgian Ministry of Soc. Affairs, available at: http://www.ose.be/ files/docPP/researchOMC.pdf; European Governance, $A$ White Paper, Coмm'n of The Eur. ComMUNities, July 25, 2001; Communication from the Commission, European Governance: Better Lawmaking, Сомm' of the Eur. Communities May 5, 2002; Communication from the Commission-Towards a Reinforced Culture of Consultation and Dialogue-General Principles and 
tion processes within the new "governance" on the same level as small NGOs and individuals, identified innocuously as "stakeholders," from where far-reaching policies and plans are prepared. ${ }^{135}$ Anderson points out, "[o]ne of the paradoxes of the present age is the extent to which states have created the machinery for limiting their capacity to intervene in economic affairs." 136

Indeed, Anderson claims that lawyers have come late to this globalization debate, ${ }^{137}$ although Philip Alston asserted in 1997 that "[i]nternational lawyers have, in many respects, served as the handmaidens of the changes wrought by globalization." ${ }^{138}$ International law and, indeed, human rights law has been premised on the existence and sovereignty of the state, but in reality the world now belongs to multinational corporations. Concurrently, the development of "transgovernmentalism," where individual elements of states (or civil servants) interact directly with their counterparts abroad, is creating a new order. ${ }^{139}$ A new technocratic elite deals with important issues, but operates not through law or rights, but through sharing information, developing common principles and soft law measures at the sub-national level across states. ${ }^{140}$

Santos claims that these developments involve the silencing of critical theory, creating a new politically disempowering terminology. The governance approach

Minimum Standards for Consultation of Interested Parties by the Commission, COM (2002) 704 final (Dec. 11, 2002); Elissaveta Radulova, The Open Method of Coordination as a New Mode of EU Governance. Paper to the First PCE Conference, June 29, 2005, Maastricht, Neth.

135. It is worth pointing out that the EU was founded to control the use of coal and steel for armaments, to prevent further inter-European wars and to facilitate trade and development of corporations across Europe. Indeed, the greatest part of EU law-Regulations, Directives, etc.-relates to standardization of products and services, thus assisting Europe-wide corporations to trade more easily.

136. Anderson, supra note 120, at 29 (2005). The High Level Group on the future of social policy in the EU pointed out in 2004 that "legislative action is more behind us than before us for several structural reasons." Report of the High Level Group on the Future of Social Policy in an Enlarged European Union (European Commission 2004), available at http://ec.europa.eu/ employment_social/news/2004/jun/hlg_social_elarg_en.pdf.

137. Anderson, supra note 120 , at 3 . Of course, legal systems as well as commercial, property, contract, international trade and other laws have provided the legitimacy and enforcement mechanisms for globalization.

138. Philip Alston, The Myopia of the Handmaidens: International Lawyers and Globalization, 3 Eur. J. Int’L L. 435 (1997).

139. See Anne-Marie Slaughter, Governing the Global Economy Through Government Networks, in The Role of Law in International Politics 177 (Michael Byers ed., 2003); Sol Picciotto, Networks in International Economic Integration: Fragmented States and the Dilemmas of Neo-Liberalism, 17 Nw. J. INT'L L. \& Bus. 1014 (1996-1997).

140. For a response to Alston's article see Shirley V. Scott, International Latuyers: Handmaidens, Chefs, or Birth Attendants? A Response to Philip Alston 9 Eur. J. INT'L L.750 (1998). 
offers alternatives to these silenced concepts which define themselves by opposition to the legitimacy concepts; "rather than social transformation, problem-solving; rather than popular participation, selected-in stakeholders' participation; rather than social contract, self regulation; rather than social justice, positive sum games and compensatory policies; rather than power relations, coordination and partnership; rather than social conflict, social cohesion and stability of flows." ${ }^{\prime 41}$

He identifies seven types of legal developments within global perspectives. ${ }^{142}$ These types are the transnationalization of nation-state law; the development of legal regimes of regional integration; transnational commercial regulation (lex mercatoria); the "law of people on the move" (migrants, refugees, and displaced persons); law of indigenous peoples; human rights and global law embodied in the idea of a common heritage of mankind. Santos sees the first three as relating to global capitalism and the last four as providing foci for cosmopolitan, anti-hegemonic, and utopian legalities. ${ }^{143}$

Francis Snyder describes the impact of globalization on legal theory, law, and the governance of globalization evolving into five areas. These involve, firstly, contracts between states, companies, etc., consecrated into international agreements and, secondly, multilevel governance (such as in the European Union) and federal states. Thirdly, the growing level of international public and private networks in all areas raises problems for national democracy and especially regulation. Fourthly, lex mercatoria, the modern law of trade, is a mix of public and private authority, involving reflexive law or a form of regulated self-regulation. A fifth area of global governance is defined by Snyder as sites of global legal pluralism, which are unique to globalization and may be public, private, or hybrid with an emphasis on strategic action. The internationalization of human rights is an example of global governance, as is the social construction of the "non-market economy."

National legal fields become internationalized in two ways. First, national legal and political arenas are increasingly influenced by external factors. Second, "domestic" decisions or laws are actually conditioned, shaped, or made elsewhere as transnational legal regimes penetrate national legal fields. The growth of trans-

141. See Santos, supra note 131 , at 35.

142. Boaventura de Sousa Santos, Toward a New Common Sense: Law, Science and Politics in Paradigmatic Transition 313 (1995) (quoted in William Twining, Globalisation and Legal Theory 239-40 (2000)). See also Boaventura de Sousa Santos, Toward a New Legal Common Sense: Law, Globalization, and Emancipation (2002).

143. See Twining, supra note 142 , at 240.

144. Francis Snyder, Economic Globalization and the Law in the Twenty-First Century, in THE Black well Companion to Law and Society 624, 630 (Austin Sarat ed., 2004). 
national networks based on "soft law" with uncertain legal status and the growing concept of global legal pluralism are some outcomes of globalization. ${ }^{1+5}$

While acknowledging the difficulties in creating one accepted definition of globalization, Robert McCorquodale and Richard Fairbrother point out that "globalisation has thus been transformative in terms of a reconceptualization of state sovereignty within both international relations and international law." ${ }^{166}$ They posit that there are a number of opportunities to develop a rights approach and corporate social responsibility within the international treaties and the WTO, in the IMF policy on good governance, and in the activities of transnational corporations. ${ }^{147}$

All of this has a major impact on the advancement of housing rights. Governments, as well as minorities within a state, are marginalized as power is transferred to bureaucrats and special interest groups, together with the increasing privatization of public functions. The ability of governments to protect human rights, even when there are constitutional and legal provisions enforced by an independent judiciary, is becoming more restricted in the development of integrated housing markets. ${ }^{148}$

Yet, it is widely acknowledged that the national state remains essential for providing the legal, economic, and social infrastructure for global capitalism and enabling markets to flourish. Of course, the state's role in allocating resources, dealing with social goods, and protecting human rights are all increasingly sublimated to the market in this era of neo-liberal globalization. ${ }^{149}$ At the heart of this problem lie important questions about how globalization has changed the nature of the relationship of markets to the state, creating a democratic deficit and necessitating new roles for administrative law. ${ }^{150}$ Equally, the growth of New Public Management (NPM) within public services since the 1980s raises fundamental, and as yet unresolved, questions about traditional administrative law relationships to contemporary human rights development. ${ }^{151}$

Yet, the Foundation for Global Governance posits that a "global civic ethic"

145. Id.

146. Robert McCorquodale \& Richard Fairbrother, Globalization and Human Rights, 21 Hum. RTs. Q. 735, 737 (1999).

147. Id.

148. Id. at 747 .

149. Id.

150. See Alfred C. Aman Jr., Globalization, Democracy and the Need for a New Administrative Law, 49 UCLA L. Rev. 1687 (2002).

151. NPM is seen as a move away from the tradition of public accountability embodied in progressive public administration ideals to economistic, managerialist approaches free from political influence and only rarely subject to judicial review. See Micha el Barzelay, The New Public Management (2001); Christopher Hood, The "New Public Management" in the 1980s: Variations on a Theme, Accr. 
should be developed, reinforced by the belief that governance should be underpinned by democracy at all levels and ultimately by the rule of enforceable law. ${ }^{152}$

\section{H. Globalization's Effects on Housing Policy}

The impact of globalization on housing policy has been enormous. Peter Marcuse has pointed out that globalization has accentuated a recommodification of housing, and in Europe a reversal of the post-War trend of public housing for the "broad masses of the population." 153 Cross-border mobility of capital and higher-echelon labor is creating demand for exclusive high-end developments, separated physically and socially from working class and poor housing. Largescale international real estate investment facilitates the substitution of private for public initiatives in land use, planning, and housing at an ever increasing scale. Globalization increases pressures in the direction of deregulation and withdrawal of government subsidies as a matter of general public policy, with ideological opposition to expansive social welfare programs. There is a stimulation of competition among cities, which puts a premium on attracting and serving high-end businesses and residences and discourages social welfare approaches. In the former socialist countries, the handling of issues of legal tenure and property rights have undermined existing housing arrangements without substituting anything better and rest on fundamental misconceptions of what property rights mean. Most importantly, globalization creates income polarization effects that increase the difference between the housing conditions of the best housed and the worst housed (and homeless) and lead to a pattern of segregation, walling, fortification, and citadelization. This is one of the most egregious impacts of globalization on housing and living conditions generally. The ultimate symbols are the citadels of housing in the hills of São Paolo_-gated communities reached only by helicopters. ${ }^{154}$ David Clapham points out that globalization involves the reorientation of

Org. \& Soc. 93 (1995). See also Judicial Review and Bureaucratic Impact: Judicial Review and Compliance with Administrative Law (Marc Hertogh \& Simon Halliday eds., 2004).

152. See the Commission on Global Governance, Our Global Nighborhood: The Report of the Commission on Global Governance (1995).

153. Peter Marcuse, Neo-liberal Globalization and National Housing Policy (paper presented at the ENHR Conference in Vienna in July 2002, summary available at http://ww w.europa forum.or.at/ site/HomepageENHR2002_neu/e/ENHR_Docu_ENG.pdf).

154. It is estimated that eight out of every ten new urban residential developments in the United States are gated. Land Use Law, Housing and Social and Territorial Cohesion 5 (Juli Ponce Sole ed., trans., 2006). 
national governments in a climate where regulation and control are increasingly difficult. ${ }^{155}$ The danger of a flight of capital and jobs constrains taxation and public expenditure policies, resulting in reduced housing expenditure. This has accompanied an emphasis on targeted spending, "value for money" approaches, and the privatization of state-owned housing. Regional economic imbalances arising from policies of flexible labor markets and freedom to locate, given to corporations, have resulted in housing shortages in some areas and surpluses in orhers. The flexible labor market approach increases the risk of episodes of poverty, with housing systems unable to respond adequately. Increased risk in the labor market has been transferred to housing through the deregulated housing finance system. Indeed, the role of planning is increasingly seen as merely supporting the housing market, even an overheated housing market. There is an emphasis on the supply of new housing in areas of economic growth and consequent high demand. ${ }^{156}$

James Kushner claims that worldwide ethnic and class-based segregation in residential areas is increasing. ${ }^{157}$ This takes place against a background of antidiscrimination laws, inclusionary land use and housing policies, subsidized supply of new housing, affirmative action programs, and planning design policies. While segregation was often installed in the past by government policy, it is maintained today through exclusionary zoning, housing cost-inflation, land use controls, and the invisible hand of freedom of choice. None of the existing, enlightened, State, strategic, and legal approaches are likely to significantly reduce or reverse the worldwide pattern of worsening ethnic and class-based segregation. There is a recognition that social cohesion or social inclusion can be incorporated into legislation, as in the case of Valencia in Spain. ${ }^{158}$

In the United States and many other countries, the growth of low density suburban housing known as urban sprawl has led to major subsidies for infrastructure and services, as well as major environmental costs. The zoning of such detached family homes in suburban areas has led to segregation with poorer households confined to inner city areas in the United States. This is motivated by a desire to "protect the aesthetics and property values of established areas or by economic class bias or racial discrimination."159 Giddens developed the concept of

155. Clapham, supra note 84 , at 55 .

156. Id.

157. See J.A. Kushner, New Urbanism: Urban Development and Ethnic Integration in Europe and the United States, in Land Use Law, Housing and Social and Territorial Cohesion, supra note 154.

158. See Valencia Housing Law 8/2004, art. 39, 59, 61.

159. See E.H. Ziegler, Urban Sprawl, Social Cohesion and Zoning Discrimination in the United States, in Land Use Law, Housing and Social and Territorial Cohesion, supra note 154. 
a "reflexive modernity," where in late modernity intensified globalization provides the individual with a range of imagery and information on models of citizenship, styles of consumption, modes of communication, etc. ${ }^{160}$ One of the consequences has been an individually increased expectation of personal fulfillment and satisfaction, often reflected in housing consumption and the lifestyle and status nature of certain housing types and locations. ${ }^{161}$ The requirements of individuals tend to be expressed more and more as individual consumer choices, fashioned to individual lifestyles, in both private and public housing. Housing policy, and indeed social commentary on housing, is expressed in market-based consumer jargon, reflecting the contemporary hegemony of the commodity and consumer aspects of housing provision and distribution. ${ }^{162}$ Globalization poses considerable problems for the traditional social-democratic models of housing policy, which involve equality and community through state action. For instance, bureaucratic allocation systems do not have the ability to take into account the full scope of households' wants and needs or to be able to accept households' own definitions of what those needs are. ${ }^{163}$

\section{Movements of People}

Stuart Hall attributes increased migration to the consequences of globalization:

Migration is increasingly the joker in the globalization pack, the subterranean circuit connecting the crisis of one part of the global system with the growth rates and living standards of the other. The logic of globalization says that every element of growth must be free to move fluidly across every regulative boundary, including that of the nation-state: capital, investment, commodities, technologies, currencies, profits, cultural messages, and images all flow. ${ }^{164}$

160. Giddens, supra note 6, at 153.

161. See Alastair Hudson, Equity, Individualization and Social Justice: Towards a New Lau of the Home, in New Perspectives on Property Law, Human Rights and the Home 1 (Alastair Hudson ed., 2004).

162. See Padraic Kenna, Housing Rights-The New Benchmarks for Housing Policy in Europe?, 37 URB. L. 87, 111 (2005).

163. Clapham, supra note 84 , at 67.

164. Hall, supra note 118 , at 34 . 
One major impact on states has been the rise in numbers of refugees and asylum seekers and their awareness of life in other states. James Goldston points out:

In recent years, while globalization has resulted in increased migration across national borders, the primary avenues for obtaining citizenship-birth on a country's territory (jus soli), descent from a citizen ( $j u s$ sanguinis), and naturalization-have not changed. As a result, growing numbers of persons - as many as 175 million worldwide-are not citizens of the countries in which they reside. ${ }^{165}$

There are currently an estimated 10.4 million refugees and as many as 25 million uprooted civilians in their own countries, so-called internally displaced persons. ${ }^{166}$ Hall states:

Seeking by whatever means-legal or illegal - to escape the consequences of globalization and the new world order, they move along uncharted routes, secrete themselves in the most inhospitable interstices, mortgage their worldly goods to the human traffickers, seal life-threatening contracts with gang-masters and pimps, and exploit their lateral family connections in order to subvert the physical barriers, legal constraints, and immigration regimes that metropolitan powers are vigorously putting in place. These are the overspill of the global system, the world's surplus populations, the sans-papiers of the modern metropolis, who slip across borders at the dead of night or stow away in the backs of lorries or under trains and silently disappear into the hidden depths of the city. This is the human face of the new globalization 'from below'. The global cities of the developed world are the sluice-gates of this new tidal movement. ${ }^{167}$

While capital and currencies are on the move, there remains a requirement on the nation-state to impose strict controls on labor (e.g., wage levels, working conditions, and employment rights) at the national level to facilitate international corporations. Although some migrant workers are permitted, such as those sea-

165. James A. Goldston, Holes in the Rights Framework: Racial Discrimination, Citizenship, and the Rights of Noncitizens, 20 ETHucs \& INT'L AfF. 321, 322 (2006).

166. UNHCR: The U.N. Refugee Agency, http://www.unhcr.ch/ (last visited Apr. 3, 2008).

167. Hall, supra note 118 , at 35-36. 
sonal and casual workers, this exception does not undermine the general model of national-state controls on labor. Hall also states that:

in spite of the logic of the system, there has been an unprecedented explosion in the largely unplanned movement of peoples across the globe. Whether fleeing the consequences of mass poverty, malnutrition, and unemployment in search of better economic or personal opportunities, or displaced by political violence, regime change, persecution, religious conflict, ethnic cleansing, or civil war, those people stigmatized as 'economic migrants', refugees, and asylumseekers now constitute the homeless multitudes of the modern metropolitan city. ${ }^{168}$

A significant aspect of this migration and its consequences for housing rights relates to women. In the book Global Woman: Nannies, Maids and Sex Workers in the New Economy, ${ }^{169}$ Barbara Ehrenreich and Arlie Hochschild point out:

Thanks to the process we loosely call "globalization," women are on the move as never before in history. In images familiar to the West from television commercials for credit cards, cell phones, and airlines, female executives jet about the world, phoning home from luxury hotels and reuniting with eager children in airports. But we hear much less about a far more prodigious flow of female labor and energy: the increasing migration of millions of women from poor countries to rich ones, where they serve as nannies, maids, and sometimes sex workers....

... Overall, half of the world's 120 million legal and illegal migrants are now believed to be women. ${ }^{170}$

For these migrants, housing is intimately connected to their employment within the home of others, and they are vulnerable to homelessness or unemployment.

Almost half a million people annually apply to European states seeking asy-

168. Id. at 35 .

169. Global Woman: Nannies, Maids and Sex Workers in the New Economy (Barbara Ehrenreich \& Arlie Russell Hochschild eds., 2003).

170. Id. at 2,5 . 
lum. ${ }^{171}$ The situation of migrants in Europe has been described by Gerald P. Daly as one where the barrier of citizenship increasingly justifies discrimination and exclusion. ${ }^{172}$ "Across Western Europe ... migrants are [being] segregated, confined to menial jobs and relegated to the worst housing in the least desirable districts of large cities. A growing polarisation is evident between average citizens and those without full rights."173

Whereas national states dealt with asylum and refugees issues separately, there is now a developed EU-wide policy in relation to asylum seekers. ${ }^{174}$ However, not all EU states have adopted this directive. ${ }^{175}$ European and other states have accepted obligations under the 1951 Convention Relating to the Status of Refugees and its Protocol to take a share of the world's refugees who are fleeing from persecution and violence. The long-term housing issues are problematic and there are varying levels of protection. In an earlier publication, I mentioned that there are now eight levels of protection of housing rights in the European Union depending on the status of the person involved. ${ }^{176}$ Indeed, it is significant that the EU Race Directive prohibiting discrimination on ethnic or race grounds in areas such as housing does not apply to noncitizens of EU states. ${ }^{177}$

At the same time, however, the Council of Europe has voiced considerable

171. European Council on Refugees and Exiles, Asylum Applications Submitted in Europe in 2001-2005, http://www.ecre.org/factfile/ECREUN2005.xls.

172. Gerald Daly, Homeless: Policies, Strategies, and Lives on the Street 89-95 (1996).

173. Bill Edgar et al., Immigration and Homelessness in Europe 7 (2004) (quoting Daly, supra note 172).

174. See Communication from the Commission, Towards more accessible, equitable and managed asylum systems, COM(2003) 315 final OJ C76/21 (June 3, 2003); Communication from the Commission on the common asylum policy and the Agenda for protection COM(2003) 152 final OJ C76/2 (Mar. 26, 2003); Commission communication on improved effectiveness, enhanced interoperability and synergies among European databases in the area of Justice and Home Affairs $\operatorname{COM(2005)} 597$ final (Nov. 24, 2005); Terri Givens \& Adam Luedtke, EU Immigration Policy: From Intergovernmentalism to Reluctant Harmonization, in The State of the European Union: Law, Politics, and Socieтr (Tanja A. Borzel \& Rachel A Cicowsk eds., 2003); Statewatch, Refugees and Asylum-Seekers: NO, "Legal Migration": YES, http://www.statewatch.org/news/NEWSINBR/05migration.htm.

175. See generally Freedom, Security and Justice, Towards a Common European Asylum System, http://europa.eu.int/comm/justice_home/doc_centre/asylum/doc_asylum_intro_en.htm (for details of all EU Instruments relating to asylum-seekers).

176. KeNNA, supra note 134.

177. A rticle 3(2) states that coverage does not include "difference of treatment based on nationality and is without prejudice to provisions ... relating to entry into and residence of third country national and stateless persons on the territory of Member States." See Council Directive 2000/43, 2000 O.J. (L180) 22, 24 (EC). 
concern over the plight of irregular migrants. ${ }^{178}$ In 2000, the Council of Europe Committee of Ministers adopted a Recommendation on the Right to Satisfaction of Basic Material Needs of Persons in Situations of Extreme Hardship. This acknowledged that "the satisfaction of basic human material needs (as a minimum: food, clothing, shelter, and basic medical care) is a requirement intrinsic to the dignity of every human being and constitutes the condition for the existence of all human beings and their well-being."179

\section{What are Housing Rights?}

\section{A. Introduction to Housing Rights}

The concept of housing as a human right is established in many international human rights instruments and has generated a body of jurisprudence and literature. ${ }^{180}$ At a minimum, housing rights are rooted in the concept of human dignity. ${ }^{181}$ Housing rights are seen as an integral part of economic, social, and cultural rights within the United Nations, ${ }^{182}$ European, Inter-American, and African human rights instruments. ${ }^{183}$ Aspects of housing rights are regularly adjudicated in courts through-

178. See Ryszard Choleminski, Irregular Migrants: Access to Minimum Social Rights 7 (2005).

179. Eur. Parl. Ass., Recommendation of the Comm. of Ministers, $694^{\text {th }}$ Meeting, Doc. No. R (2000) 3 (on the right to satisfaction of basic material needs of persons in situations of extreme hardship).

180. See U.N.-HA BITAT, Housing Rights Legislation: United Nations Housing Rights Programme, Report No. 1, U.N. Doc. HS/638/01 E (2002) (describing international and national legal housing rights resources); KenNa, supra note 134; Legal Resources for Housing Rights (Scott Leckie ed., 2000) (describing international and national legal housing rights resources) [hereinafter Legal. Resources].

181. Religious groups often discuss housing rights in relation to natural law rights. In Genesis 9:6, the image of God in man is stated. The emphasis on kavod in Jewish thought is fully paralleled by the western and eastern Christian reference to the Imago Dei concept in relation to the concept of human dignity. Of course, the Imago Dei, or image of God, is to be found in earlier Mesopotamia and in ancient Egypt. See Dietrich Ritschl, Can Ethical Maxims Be Derived From Theological Concepts of Human Dignity?, in The Concept of Human Dignity in Human Rights Discourse 87, 91 (David Kretzmer \& Eckert Klein, eds., 2002) (discussing how human dignity as a concept derived from theology, and plays an important role in ethics).

182. See Mathew C.R. Craven, The International Covenant on Economic, Social, and Cultural Rights 329 (1995); Economic, Social and Cultural Rights: A Textbook 149 (Ashjorn Eide et al. eds., 2d ed. 2001); UN-HABITAT, International Instruments on Housing Rights (2002), available at http://www.unhabitat.org/pmss/getPage.asp? page $=$ bookView $\&$ book $=1281$.

183. Human Rights Education Association, The Right to Housing, http://www.hrea.org/index .php? base_id = 149 (last visited Apr. 5, 2008) (listing international agreements that include the right to housing). 
out the world, ${ }^{184}$ including in the United States, ${ }^{185}$ with contemporary South African jurisprudence in this area attracting keen academic interest. ${ }^{186}$ At a national level, at least 40 percent of the world's constitutions refer to housing or housing rights. ${ }^{187}$

Scott Leckie points out that since the 1990s, the international legal, conceptual, practical, and philosophical evolution of housing rights has provided a solid legal basis for future development. ${ }^{188}$ The Cold War is now more than a decade in the past, and it is therefore legitimate to place socio-economic rights, such as housing rights, alongside long-revered civil and political rights. The Vienna Declaration (1993) states that both sets of rights are "universal, indivisible, interdependent and interrelated. The international community must treat human rights globally in a fair and equal manner, on the same footing and with the same emphasis." 189

Clarification on the contents and obligations of housing rights, including the concepts of minimum core obligations, progressive realization of rights according to available resources, and violations of rights are now widely understood and accepted. ${ }^{190}$ Indeed, Leckie claims that the international legal foundations of the human

184. See generally Litigating Economic, Social and Cultural Rights: Achievements, ChalLenges and Strategies (Malcolm Langford \& Aoife Nolan eds., 2003) (case studies illustrating that a wide variety of economic, social, and cultural rights are indeed justiciable); TARA Melish, Protecting Economic, Social and Cultural Rights in the Inter-American Human Rights System: A Manual on Presenting Claims (2002) (a comprehensive guide to bringing economic, social, and cultural rights claims in the Inter-American human rights system); Aoife Nolan, Litigating Housing Rights: Experiences and lssues, 28 Dublin U. L.). 145 (describing how complaints made about housing rights violations by states have been litigated before courts and other judicial or quasi-judicial decision-making bodies).

185. See generally Beth Harris, Defending the Right to a Home: The Power of Anti-PovERTY LAWYERS (2004) (looking at responses of poverty lawyers to the social welfare law reforms of the United States Congress and state legislatures).

186. See Jaftha v. Van Rooyen 2005 (2) SA 140 (CC) (S. Afr.); Port Elizabeth Municipality v. Various Occupiers 2005 (1) SA 217 (CC) (S.Afr.); City of Cape Town v. Rudolph 2004 (5) SA 39 (C) (S. Afr.); Government of South A frica v. Grootboom, 2001 (1) SA 46 (CC) (S. Afr.).

187. Legal Resources, supra note 180 , at $45,60-71$. It is important to note that housing rights are legally guaranteed at the national level in areas of property law, family law, landlord/tenant law, succession law, law of equity and trusts, consumer law, and other areas of law.

188. Id. at 1 .

189. The Secretary-General, Report of the Secretary General on the Vienna Declaration Programme of Action, U.N. Doc. A/CONF 157/24 (Part I) (Oct. 13, 1993).

190. See Adequate Housing, supra note 5. Much work has been carried out on defining the specific rights contained in the Covenant especially by the U.N. Committee on Economic, Social and Cultural Rights in its Conclusions and Reports. See generally Office of the High Commissioner for Human Rights, Committee on Economic, Social, and Cultural Rights, http://www.unhchr.ch/html/ menu2/6/cescr.htm (listing examples of Committee on Economic, Social, and Cultural Rights documents); Philip Alston \& Gerard Quinn, The Nature and Scope of States Parties' Obligations 
right to adequate housing are inherent in a multi-faceted global social contract, designed to ensure access to a secure, adequate, and affordable home for all people in all countries. ${ }^{191}$

\section{B. The United Nations Instruments}

Since 1948, most states across the world have accepted that their citizens have housing and other rights. The Universal Declaration of Human Rights (UDHR) of 1948, adopted by almost all states, recognizes rights to housing. Article 25 states:

(1) Everyone has the right to a standard of living adequate for the health and well-being of himself and of his family, including food, clothing, housing and medical care and necessary social services, and the right to security in the event of unemployment, sickness, disability, widowhood, old age or other lack of livelihood in circumstances beyond his control. ${ }^{192}$

Similarly, the International Covenant on Economic, Social and Cultural Rights (ICESCR), of 1966, now ratified by almost 150 states (though not the United States), recognizes the right to housing. ${ }^{193}$ Article 11 states:

Under the International Covenant on Economic, Social and Cultural Rights, 9 Hum. Rrs. Q. 156 (1987) (arguing, while continuing to endorse the argument that more effective inclusion of economic, social, and cultural rights within the community of human rights is fundamentally important, that the original promise of the Universal Declaration of Human Rights that human dignity should be pursued in light of both the overarching purposes and the underlying values of human rights protection, rather than under the constraint of false dichotomies); Jack Donnelly \& Rhoda E. Howard, Assessing National Human Rights Performance: $A$ Theoretical Framework, 10 Huм. Rтs. Q. 214 (1988) (narrowing the list of rights concerning which it is necessary to gather data by establishing a theoretical framework for assessing a state's human rights performance by identifying a set of ten essential rights that are separately, intrinsically essential and together provide good proxies for almost all other rights); Dipak K. Gupta et al,, Creating a Composite Index for Assessing Country Performance in the Field of Human Rights: Proposal for a Neu Methodology, 16 Hum. RTs. Q. 131 (1994) (providing a new methodology for attributing weights to the various indicators of human rights abuse to achieve a more objective measurement of human rights performance).

191. National Perspectives on Housing Rights 3 (Scott Leckie et al. eds., 2003).

192. Universal Declaration of Human Rights, G.A. Res. 217A, at 71, U.N. GAOR, 3d Sess., 1st plen. Mtg., U.N. Doc. A/810 (Dec. 12, 1948).

193. See International Covenant on Economic, Social, and Cultural Rights, G.A. Res. 2200A (XXI), U.N. Doc. A/6316 (Dec. 16, 1966) [hereinafter ICESCR]; Office of the UNIted Nations High Commissioner for Human Rights, Status of Ratifications of the Principal International Human Rights Treaties (June 9, 2004), http://www.unhchr.ch/pdf/report.pdf. 
The States Parties to the present Covenant recognize the right of everyone to an adequate standard of living for himself and his family, including adequate food, clothing and housing, and to the continuous improvement of living conditions. The States Parties will take appropriate steps to ensure the realization of this right, recognizing to this effect the essential importance of international cooperation based on free consent. ${ }^{14}$

States are required to recognize housing rights, use the maximum of available resources to achieving progressively the full realization of these rights, meet "minimum core" obligations, ensure nondiscrimination, and enact legislative measures and appropriate policies geared to a progressive realization of these rights. ${ }^{195} \mathrm{Gen}$ eral Comment No. 4: The Human Right to Adequate Housing sets out the elements of adequate housing forming the minimum core guarantees which, under public international law, are legally vested in all persons. ${ }^{196}$ General Comment No. 7: The Right to Adequate Housing seeks to prohibit forced evictions that result in individuals being rendered homeless or vulnerable to the violation of other human

194. ICESCR, supra note 193, art. 11(1).

195. The State's domestic obligations under the ICESCR Covenant are set out in Art 2:

Each State Party to the present Covenant undertakes to take steps, individually and through international assistance and co-operation, especially economic and technical, to the maximum of its available resources, with a view to achieving progressively the full realization of the rights recognized in the present Covenant by all appropriate means, including particularly the adoption of legislative measures. The States' Parties to the present Covenant undertake to guarantee that the rights enunciated in the present Covenant will be exercised without discrimination of any kind as to race, colour, sex, language, religion, political or other opinion, national or social origin, property, birth or other status." ICESCR, supra note 193, art. 2(2). See also Alston \& Quinn, supra note 190, at 65.

196. See ECOSOC, Comm. on Econ. Soc. and Cult. Rights, General Comment No. 4: The Human Right to Adequate Housing, II 8, U.N. Doc. E/1992/23 (1991). These elements are legal security of tenure, availability of services, materials and infrastructure, affordable housing, habitable housing, accessible housing, housing in a suitable location, and housing constructed and sited in a way which is culturally adequate. $I d$. 
rights. ${ }^{197}$ Other General Comments refer to housing rights in the context of people with disabilities, ${ }^{198}$ older people, ${ }^{199}$ health rights, ${ }^{200}$ and other areas.

The U.N. Convention on the Elimination of All Forms of Discrimination Against Women (CEDAW) ${ }^{201}$ refers to State obligations to ensure equality in relation to the right to bank loans, mortgages, and other forms of financial credit. ${ }^{202}$ It promotes women's rights to enjoy adequate living conditions, particularly in relation to housing, sanitation, electricity, water supply, transport, and communications. ${ }^{203}$ There is a powerful argument that an understanding of women's actual housing experiences must inform a definition of women's right to housing.

Despite the fact that, worldwide, women are the primary users of housing and are therefore the most affected by housing, women have been excluded from virtually every aspect of the housing process, be it policy development, planning and design, ownership, construction and even housing movements. And so, though the house is a 'woman's place,' in most communities she is not permitted to control it. ${ }^{204}$

197. According to paragraphs 10-16, where those affected are unable to provide for themselves, the State Party must take all appropriate measures, to the maximum of its available resources, to ensure that adequate alternative housing, resettlement, or access to productive land, as the case may be, is available. ECOSOC, Comm. on Econ., Soc. and Cult. Rights, General Comment No. 7: The Right to Adequate Housing: Forced Evictions, U.N. Doc. E/C.12/1997/10 (May 14, 1997); see also Leilani Farha, Is There a Woman in the House? Women and the Right to Adequate Housing (1998) http://cesr.org/filestore2/download/480/womenhousing.pdf.

198. See ECOSOC, Comm. on Econ., Soc., and Cult. Rights, General Comment No. 5 (1994): Persons with Disabilities, 99 II 33, U.N. Doc. E/1995/22 (Nov. 25, 1994). In the U.N. Convention on the Rights of Persons with Disability, Art. 28, Adequate Standard of Living and Social Protection, states: "States Parties recognize the right of persons with disabilities to an adequate standard of living for themselves and their families, including adequate food, clothing, and shall take appropriate steps to safeguard and promote the realization of this right without discrimination on the basis of disability." Convention on the Rights of Persons with Disabilities, G.A. Res. 61/106, $76^{\text {th }}$ plen. mtg., U.N. Doc. A/RES/61/106 (Dec. 13, 2006).

199. See ECOSOC, Comm. on Econ., Soc., and Cult. Rights, General Comment No. 6 (1995): The Economic, Social, and Cultural Rights of Older Persons, 97 I 32, U.N. Doc. E/1996/22 (Nov. 24, 1995).

200. See ECOSOC, Comm. on Econ., Soc., and Cult. Rights, General Comment No. 14 (2000): The Right to the Highest Attainable Standard of Health, I 3, U.N. Doc. E/C.12/2000/4 (Aug. 11, 2000).

201. Convention on the Elimination of All Forms of Discrimination Against Women, G.A. Res. 34/180, at 193, U.N. GAOR 34 ${ }^{\text {th }}$ Sess., 107 ${ }^{\text {h }}$ plen. mtg., U.N. Doc. A/34/46 (Dec. 18, 1979) [hereinafter CEDAW]. Some 180 States were parties to CEDAW as of March 2005. See U.N. Division for the Advancement of Women, States Parties, http://www.un.org/womenwatch/daw/cedaw/states.htm.

202. CEDAW, supra note 201, art. 13.

203. Id. at art. 14(2).

204. Farha, supra note 197 , at 6. 
The Limburg Principles (1986) ${ }^{205}$ and the Maastricht Guidelines (1997) ${ }^{206}$ have defined further the requirements of effective implementation of socio-economic rights and the nature and appropriate remedies for violations. ${ }^{207}$ The Maastricht Guidelines recommend that any person or group who is a victim of a violation of an economic, social, or cultural right (including housing rights) should have access to effective judicial or other appropriate remedies at both national and international levels. ${ }^{208}$ Of course, the violation of the right to adequate housing may have different meanings for women and men.

A majority of the world's 1 billion people living in conditions of abject poverty are women. They make up the plurality of the world's 50,000 inhabitants who die daily from disease resulting from inadequate housing. ... An average of 50-60\% of all homeless women report that they are homeless because they are fleeing domestic violence. Eighty-one per cent of all homeless women have at some time in their lives experienced either sexual assault or physical abuse, and $65 \%$ reported physical violence by a current partner .... ${ }^{209}$

205. A group of distinguished experts in international law, convened by the International Commission of Jurists, the Faculty of Law of the University of Limburg (Maastricht, the Netherlands), and the Urban Morgan Institute for Human Rights, University of Cincinnati (Ohio, US), met in Maastricht on June 2-6, 1986, to consider the nature and scope of the obligations of States Parties to the ICESCR, the consideration of States Parties reports by the newly constituted ECOSOC Committee on Economic, Social and Cultural Rights, and international cooperation under Part IV of the Covenant. The twenty-nine participants came from Australia, the Federal Republic of Germany, Hungary, I reland, Mexico, Netherlands, Norway, Senegal, Spain, United Kingdom, United States of America, Yugoslavia, the UNCHS, ILO, UNESCO, WHO, the Commonwealth Secretariat, and the sponsoring organizations. ECOSOC, Comm. on Human Rights, The Limburg Principles on the Implementation of the International Covenant on Economic, Social, and Cultural Rights, U.N. Doc. E/CN.4/1987/17, Annex (1987). See also The Limburg Principles on the Implementation of the International Covenant on Economic, Social, and Cultural Rights, 9 Нuм Rтs. Q. 122 (1987) [hereinafter Limburg Principles].

206. The Maastricht Guidelines on Violations of Economic, Social and Cultural Rights, 20 Hum RTs. Q. 691 (1998) [hereinafter Maastricht Guidelines].

207. The Habitat International Coalition Housing and Land Rights Network has also developed a Toolkit in cooperation with the Special Rapporteur on Adequate Housing, Miloon Kothari, to provide a more comprehensive and community-based monitoring instrument for assessing the realization, or violations, of housing and land rights. This initiative identifies rights-sensitive indicators for monitoring the realization of the right to adequate housing. See Housing and Land Rights Network, Toolkit, http://toolkit.hlrn.org/ (last visited Apr. 3, 2008).

208. Maastricht Guidelines, supra note 206, at 699.

209. ECOSOC, Comm on Human Rights, Integration of the Human Rights of Women and the Gender Perspective: Written Statement submitted by Human Rights Advocates, a Non-Governmental Organization in Special Consultative Status, II 1, 9, U.N. Doc. E/CN.4/1999/95 (Mar. 11, 1999). 
The Convention on the Rights of the Child ${ }^{210}$ places obligations on accepting states to recognize the right of every child to a standard of living adequate for the child's physical, mental, spiritual, moral, and social development, and this may require the provision of housing. ${ }^{211}$

Many other international instruments setting out rights to housing have been ratified by countries around the world. ${ }^{212}$ These include:

- The Declaration on the Rights of Disabled Persons (1975) 213

- The Vancouver Declaration on Human Settlements (1976) ${ }^{214}$

- The U.N. Global Strategy for Shelter to the Year $2000^{215}$

- The U.N. World Conference on Environment and Development (UNCED) of Rio de Janeiro in 1992, which adopted Agenda 21

- ILO Recommendation No. 115 on Worker's Housing (1961)

- The U.N. Convention Relating to the Status of Refugees (1951) and its Protocol..$^{216}$

- The International Convention on the Protection of the Rights of All Migrant Workers and Members of Their Families (1990) ${ }^{217}$

- The Draft International Convention on Housing Rights (1994)218

- The Habitat Agenda (1996) ${ }^{219}$

210. See The Convention on the Rights of the Child, opened for signature Nov. 20, 1989, 1577 U.N.T.S. 3, available at http://www.unhchr.ch/html/menu3/b/k2crc.htm (last visited Mar. 19, 2008).

211. Id. at art. 27.

212. See, e.g., Legal Resources, supra note 180, at 60-70 (for a fuller compilation of these instruments); Centre on Housing Rights and Evictions, http://www.cohre.org (last visited Apr. 3, 2008).

213. G.A. Res. 3447 (XXX) U.N. Doc. A/10034 (Dec. 9, 1975), available at http://www2.ohchr. org/english/law/res3447.htm.

214. Habitat: United Nations Conf. on Human Settlements, Vancouver, Can., May 31-June 11, 1976, Vancouver Declaration on Human Settlements, available at http://www.unhabitat.org/ downloads/docs/924_21239_The_Vancouver_Declaration.pdf.

215. G.A. Res. 43/181, U.N. Doc. A/RES/43/181 (Dec. 20, 1988).

216. Convention Relating to the Status of Refugees, opened for signature July 28, 1951, 189 U.N.T.S. 150, available at http://www.unhchr.ch/html/meu3/b/o_c_ref.htm.

217. G.A. Res. 45/158, U.N. Doc A/RES/45/158 (Dec. 18, 1990).

218. ECOSOC, Sub-Comm'n on Prevention of Discrimination \& Prot. of Minorities, The Realization of Economic, Social and Cultural Rights: the Right to Adequate Housing, 1917-18, U.N. Doc. E/CN.4/Sub.2/1994/20 (June 21, 1994) (prepared by Rajinder Sachar).

219. Habitat II, Istanbul, Turkey, June 3-14, 1996, Habitat Agenda, available at http://www. unhabitat.org/downloads/docs/1176_6455_The_Habitat_Agenda.pdf. 


\section{Council of Europe Housing Rights ${ }^{220}$}

The European Social Charter (ESC) of $1961^{221}$ and its successor, the Revised European Social Charter (RESC) of 1996, ${ }^{222}$ set out a number of housing related rights and freedoms and establish a supervisory mechanism guaranteeing their respect by the states' parties. ${ }^{223}$ Since 1995, a Collective Complaints Protocol was established, allowing approved NGOs to lodge complaints against states in relation to breaches of the Charters. ${ }^{224}$

220. The Council of Europe, established in 1949 and now with forty-six Member States has promoted a rights based approach in many areas, including housing rights, through its two Social Charters and also within its European Convention on Human Rights (ECHR) with its allied European Court of Human Rights (ECHR). See Council of Europe, About the Council of Europe, http://www.coe.int/T/e/Com/about_coe/ (giving a brief summary of the Council, its history, and its aims). In 2000, the Council of Europe Committee of Ministers adopted a Recommendation on the Right to the Satisfaction of Basic Material Needs of Persons in Situations of Extreme Hardship. This acknowledged that "the satisfaction of basic human material needs (as a minimum: food, clothing, shelter and basic medical care) is a requirement intrinsic to the dignity of every human being and constitutes the condition for the existence of all human beings and their wellbeing." See Eur. Parl. Ass., Recommendation No. R (2000) 3 of the Committee of Ministers, 694 ${ }^{\text {th }}$ Meeting, (Jan. 18, 2000) at 5 (concerning the right to the satisfaction of basic material needs of persons in situations of extreme hardship).

221. Eur. Soc. Charter, Council of Europe, Oct. 18, 1961, Eur. T.S. No. 35. For a complete list of the Council of Europe's Treaties, see http://conventions.coe.int (follow "full list" hyperlink).

222. Eur. Soc. Charter (Revised), Council of Europe, Mar. 5, 1996, Eur. T.S. No. 163.

223. The binding nature at the national level of the Charters depends on whether a dualist or monist legal systems pertains, but many States have incorporated the Charter (or parts of it) into national law. For up to date details on signatures, ratifications, and reservations on the Charter and Revised Charter, see Council of Europe, http://www.coe.int. (last visited Mar. 20, 2008). See also David Harris \& John Darcy, The European Social Charter (Transnational Publishers 2d ed. 2001) (1984); Lenia Samuel, Fundamental Social Rights: Case law of the European Social Charter (Council of Europe Publishing 1997). The Committee on Social Rights (CSR) examines cyclical Contracting State and other reports on the implementation of the Charter. See Council of Europe, The Implementation of the European Social Charter in Europe's Member States: Survey by Country, http://www.coe.int/T/E/Human_Rights/Esc/6_Survey_by_country/.

224. A number of Collective Complaints addressing housing rights have been heard by the European Committee of Social Rights. See Council of Europe, European Committee of Social Rights: List of Collective Complaints and Advancement of the Procedure, available at http://www.coe.int $/ \mathrm{t} / \mathrm{e} /$ human_rights/esc/4_collective_complaints/List_of_collective_complaints/default.asp. See, e.g., Complaint No. 39/2006, FEANTSA v. France (holding that France did not meet the obligations of Article 31 despite significant public spending and extensive supports for social housing), Complaint No. 33/2006, International Movement ATD Fourth World v. France (holding that an international organization, ATD Fourth World, was competent to submit complaints under Article 16); Complaint No. 31/2005, European Roma Rights Center (ERRC) v. Bulgaria (holding that Bulgaria was in violation of Article 16 of the Revised European Social Charter on the basis that a 
The RESC contains important rights to social and medical assistance for those without adequate resources, ${ }^{225}$ establishing rights to housing in relation to physically and mentally disabled persons, ${ }^{226}$ children and young persons, ${ }^{227}$ and social, legal, and economic protection for families, including a state obligation to provide family housing. ${ }^{228}$ The RESC grants migrant workers an explicit right to be treated equally in relation to access to housing ${ }^{229}$ and sets out the right of elderly persons to social protection and independent living by means of provision of housing suited to their needs and their state of health, or of adequate support for adapting their housing. ${ }^{230}$ Article 30 of the RESC, on rights to protection against poverty and social exclusion, includes an obligation on Contracting States to promote effective access to a range of services, including housing. ${ }^{231}$

law limiting legalizing illegal dwellings had a disproportionate impact on the Roma ethnic group); Complaint No. 27/2004, European Roma Rights Center (ERRC) v. Italy (holding that Italy was in violation of Article 31 on the basis of providing insufficient housing opportunities to the Roma ethnic population); Complaint No. 15/2003, European Roma Rights Centre (ERRC) v. Greece (holding that Greece was in Violation of Article 15 on the basis that a law restricting nomadic individuals had a disproportionate impact on the Roma ethnic group). See also Robin R. Churchill \& Urfan Khaliq, The Collective Complaints System of the European Social Charter: An Effective Mechanism for Ensuring Compliance with Economic, Social and Cultural Rights, 15 Eur. J. INT'L L. 417 (2004); G. Brillat, The Supervisory Machinery of the European Social Charter: Recent Developments and their Impact, in Social Rights in Europe 31 (Grainne de Burca et al. eds., 2005).

225. Eur. Soc. Charter (Revised), supra note 222, at art. 13.

226. Id. at art. 15 .

227. Id. at art. 17.

228. Id. at art. 16. For conclusions on Finland under this Article see Council of Europe, European Committee of Social Rights Conclusions XV-1, http://hudoc.esc.coe.int/esc/search/default.asp? mode $=$ esc $\&$ language $=$ en $\&$ source $=$ re (enter " 16 " for the article, "Finland" for states and "XV" for cycles, then press search).

229. Eur. Soc. Charter (Revised), supra note 222, at art. 19. For conclusions in this area on Belgium see, Council of Europe, European Committee of Social Rights: Conclusions XIV-1, http:// hudoc.esc.coe.int/esc/search/default.asp? mode =esc\&language = en $\&$ source $=$ re (enter "19" for article, "Belgium" for states, and "XIV" for cycles, then press search).

230. Eur. Soc. Charter (Revised), supra note 222, at art. 23.

231. "By introducing into the Revised Charter a new Article 30, the Council of Europe member states considered that living in a situation of poverty and social exclusion violates the dignity of human beings. With a view to ensuring the effective exercise of the right to protection against poverty and social exclusion Article 30 requires States parties to adopt an overall and coordinated approach... The measures taken in pursuance of the approach must promote access to social rights, in particular employment, housing, training, education, culture and social and medical assistance." Council of Europe, European Committee of Social Rights: Conclusions 2003-Volume 1, at 214 [hereinafter Conclusions 2003], http://www.coe.int/t/e/human_rights/esc/3_reporting_procedure/2_ recent_conclusions/2_by_year/2003Voll_en.pdf. "In the Committee's view housing is a critical policy area in fighting poverty and it is particularly interested to know what measures have been 
Article 31 of the RESC advances a major new development in housing rights:

With a view to ensuring the effective exercise of the right to housing, the Parties undertake to take measures designed:

i. to promote access to housing of an adequate standard;

ii. to prevent and reduce homelessness with a view to its gradual elimination;

iii. to make the price of housing accessible to those without adequate resources.

The Conclusions of the CSR in monitoring Contracting States obligations under Article 31 have demonstrated the application of a new set of benchmarks to national housing law and policy. ${ }^{232}$

Under Article $31 \S 1$ of the Charter, the Committee considers that the Parties shall guarantee to everyone the right to housing and to promote access to adequate housing.... Equal treatment must be assured to the different groups of vulnerable persons, particularly low-income persons, unemployed, single parent households, young persons, persons with disabilities including mental health problems. . . . The Committee considers that, for the purpose of Article 31 $\$ 1$, the Parties must define the notion of adequate housing in law. The Committee considers that "adequate housing" means a dwelling which is structurally secure, safe from a sanitary and health point of view and not overcrowded, with secure tenure supported by the law....

The Committee considers as homeless those individuals not legally having at their disposal a dwelling or other forms of adequate shelter. The temporary supply of shelter, even adequate, cannot be held

taken to ensure an appropriate spatial distribution of (social) housing so as to avoid 'ghettoising' poverty and social exclusion." $I d$. at 218.

232. See id. at 342-45. Accord Kenna, supra note 162 (discussing approaches to housing rights and the development of the Council of Europe's monitoring system). It is important to point out that not all 46 States of the Council of Europe have accepted Article 31. States which had ratified the RESC by June 1, 2005 were: Albania, Andorra, Armenia, Azerbaijan, Belgium, Bulgaria, Croatia, Estonia, Finland, France, Ireland, Italy, Lithuania, Moldova, Norway, Portugal, Romania, Slovenia, and Sweden. See Council of Europe, European Social Charter (Revised): Table of Signatories, http:// conventions.coe.int/Treaty/Commun/ChercheSig.asp $: \mathrm{NT}=163 \& \mathrm{CM}=\& \mathrm{DF}=\& \mathrm{CL}=\mathrm{ENG}$. 
as satisfactory and the individuals living in such conditions and who wish so, shall be provided with adequate housing within a reasonable period....

The Committee considers that, for the purpose of Article 31§3, Parties shall ensure an adequate supply of affordable housing. The Committee considers housing to be affordable when the household can afford to pay the initial costs (deposit, advance rent), the current rent and/or other costs (utility, maintenance and management charges) on a long-term basis and still be able to maintain a minimum standard of living, as defined by the society in which the household is located. ${ }^{233}$

The European Convention for the Protection of Human Rights and Fundamental Freedoms (ECHR) ${ }^{234}$ contains many civil and political rights provisions leading to the development of housing rights across Europe, especially within Articles 3, 6, 8, 13, and 14 and Article 1 of Protocol No. 1.235

The provisions of Article 3 of the Convention, requiring states to ensure that no one shall be subjected to torture or to inhuman or degrading treatment or punishment, have been applied to destitute homeless people. ${ }^{236}$

233. Conclusions 2003, supra note 231, at 342,345,348. Following this clarification of the obligations under Article 31, key indicators of rights to housing in general were presented by Professor Matti Mikkola, a member of the CSR, to include: immediate access to adequate tempora ry housing; a share of social rented housing (5-15 percent of aggregate housing); a maximum waiting period for social rented housing of six to twelve months; conditions for fair contracts in law, including termination of tenure and protection against harassment, threats, and forced eviction; demands of health, hygiene, and basic amenities, as well as criteria of suitability in law. See Housing Rights in Europe Conference, Helsinki, Fin., Sept. 18-19, 2006, Housing Rights in Council of Europe, http://www.ymparisto.fi/ download.asp? contentid $=56520 \&$ lan $=$ en (for more details on Professor Mikkola's indicators).

234. Convention for the Protection of Human Rights and Fundamental Freedoms, Council of Europe, Dec. 10, 1948, Eur. T.S. No. 005, available at http://conventions.coe.int/treaty/en/Treaties/ Html/005.htm.

235. A further Protocol 12 was recently introduced, prohibiting discrimination by public bodies in all areas of discrimination not covered by Article 14. It is significant that the protection of the Convention applies to anyone resident in the countries who have adopted it, regardless of status. See Protocol No. 12 to the Convention for the Protection of Human Rights and Fundamental Freedoms, Council of Europe, Nov. 4, 2000, Eur. T.S. No. 177 at art. 1.

236. For instance, the House of Lords in England has ruled that the State has such obligations to failed asylum-seekers who remained in the State and were destitute with no assistance available to them. The Court considered the question as to what level of abject destitution such individuals must sink before their suffering or humiliation reaches the "minimum level of severity" to amount to "in- 
In the case of Moldovan and Others v. Romania, ${ }^{237}$ the European Court of Human Rights (ECtHR) concluded that the applicants' living conditions and the racially discriminatory manner in which their grievances were handled by the public authorities constituted an interference with their human dignity. In the special circumstances of the case, this amounted to "degrading treatment" within the meaning of Article 3.

Article 8 of the ECHR has particular significance in relation to state obligations to respect an individual's home. It states:

(1) Everyone has the right to respect for his private and family life, his home and his correspondence.

(2) There shall be no interference by a public authority with the exercise of this right except such as is in accordance with the law and is necessary in a democratic society in the interests of national security, public safety or the economic well-being of the country, for the prevention of disorder or crime, for the protection of health or morals, or for the protection of the rights and freedoms of others.

Article $8(1)$ protects the right of individuals to "respect" for their private life, family life, and "home." There is a right to access to, occupation of, and peaceful enjoyment of the home. All of the decisions of the ECtHR reflect a Convention view of home. "Home" is an autonomous concept, which does not depend on classification under domestic law. ${ }^{238}$ The concept of a home is not confined to dwellings or land, which are lawfully occupied or owned. ${ }^{239}$ All proceedings for possession of a home engage Article $8 .{ }^{240}$ Although the Article may be engaged, justifications for interference can be on the grounds that the interference is "in

human or degrading treatment" under Article 3 of the European Convention of Human Rights' as incorporated into the UK Human Rights Act 1998. Here the State was found to have a positive obligation under Article 3 to provide accommodation and other services. See Regina v. Secretary of State for the Home Department (Appellant) UKHL 66 (2005), available at 2000 WL 280234, ๆ 7.

237. Moldovan v. Romania (No. 2), App. No. 41138/98, 44 Eur. H.R. Rep. 16, at 306 (2007) (holding in favor of Roma displaced by government action).

238. But see Chapman v. United Kingdom, App. No. 27238/94, 33 Eur. H.R. Rep. 18 (2001) (holding that government refusal to allow a gypsy's caravan to stay on land was a legitimate interference "necessary in a democratic society" and therefore not a violation of Article 8).

239. See Buckley v. United Kingdom, App. No. 20348/92, 23 Eur. H.R. Rep. 101 (1996).

240. Lambeth LBC v. Howard 33 H.L.R. 58 (2001). 
accordance with the law" or necessary in a democratic society, and proportionate to the aim sought to be achieved..$^{241}$

While there is no obligation under the ECHR for a universal state housing provision, the combination of obligations under Articles 3 and 8 can lead to further positive obligations. In Marzari v. Italy, ${ }^{242}$ the obligation for public authorities to provide assistance to an individual suffering from a severe disability, because of the impact of such refusal on the private life of the individual, was advanced. ${ }^{243}$ Such positive obligations on states to protect people's homes have been found by the ECtHR under Article 8 in relation to protection from smells and nuisance from a waste treatment plant, ${ }^{244}$ toxic emissions emanating from a chemical factory, ${ }^{245}$ environmental pollution from a steel plant, ${ }^{246}$ and noise from bars and nightclubs. ${ }^{247}$ However, in Hatton v. United Kingdom ${ }^{248}$ the ECtHR found that Heathrow airport's policy on night flights had struck a fair balance between those whose rights to respect for home had been affected and the interests of the economic well-being of the country as a whole.

The First Article of Protocol 1 of the ECHR describes state obligations to ensure the peaceful enjoyment of possessions by every legal and natural person. "Every natural or legal person is entitled to the peaceful enjoyment of his possessions. No one shall be deprived of his possessions except in the public interest and

241. See Chapman, 33 Eur. H.R. Rep. at 413; Connors v. U.K., App. No. 66746/01, 40 Eur. H.R. Rep. 9 (2004); Beard v. U.K. App. No. 24882/94, 33 Eur. H.R. Rep. 19 (2001).

242. Marzari v. Italy, App. No. 36448/97, 28 Eur. H.R. Rep. CD 175, 179 (1999).

243. The Court considers that, although Article 8 does not guarantee the right to have one's housing problem solved by the authorities, a refusal of the authorities to provide assistance in this respect to an individual suffering from a severe disease might in certain circumstances raise an issue under Article 8 of the Convention because of the impact of such refusal on the private life of the individual. The Court recalls in this respect that, while the essential object of Article 8 is to protect the individual against arbitrary interference by public authorities, this provision does not merely compel the state to abstain from such interference: in addition, to this negative undertaking, there may be positive obligations inherent in effective respect for private life. A State has obligations of this type where there is a direct and immediate link between the measures sought by the applicant and the latter's private life.

Id. at 179; see also Botta v. Italy, App. No. 21439/93, 26 Eur. H.R. Rep. 241, 248 (1998).

244. Lopez-Ostra v Spain, App. No. 16798/90, 20 Eur. H.R. Rep. 277, II 4 (1994).

245. Geurra v ltaly, App. No. 14967/89, 26 Eur. H.R. Rep. 357, 359 (1998).

246. Fadeyeva v Russia, App. No. 55723/00, I 64, ECHR 2005-IV.

247. Moreno-Gomez v Spain, App. No. 4143/02, 2004-X Eur. Ct. H.R. 327, 342.

248. 2003-VIII Eur. Ct. H.R. 189, 225-28. 
subject to the conditions provided for by law and by the general principles of international law." 49

There is a long line of ECtHR cases showing that entitlements to social assistance can amount to a property right, benefiting from the protection of Article 1 of Protocol $1 .{ }^{250}$ Stretch $v$. United Kingdom ${ }^{251}$ held that the notion of "possessions" included the tenant's interest in the continuation of a tenancy. Once this property right is established, then any interference with that right must satisfy the requirements of Article 1 of Protocol 1, Article 6, and also Article 14 in relation to nondiscrimination. ${ }^{252}$ Of course, this jurisprudence relies on protecting preexisting rights or entitlements, rather than any creation of new rights.

Deprivation of possessions in this area can include the compulsory purchase of property or possessions, a partial reduction in rights, challenges to rent controls, and legislation restricting recovery of possession or prohibiting eviction. James v. United Kingdom ${ }^{253}$ showed that Article 1 of Protocol 1 does not guarantee a right to full compensation in all circumstances. Legitimate objectives of "public interest," as pursued by measures of economic reform or measures designed to achieve greater social justice, may call for less than full market value reimbursement. ${ }^{254}$

249. Of course, in the context of globalization it is significant to recognize that corporations are invoking human rights charters to grant themselves powers and protections, particularly in relation to property rights, but also to freedom of expression and other rights, under the provisions that such rights apply to "natural or legal persons." See Anderson, supra note 120, at 125.

250. See Koia Poirrez v. France, 2003-X Eur. Ct. H.R. 73, 85-90; Gaygusuz v. Austria (No. 14), 1996-IV Eur. Ct. H.R. 1129,1140-42; Feldbrugge v. The Netherlands, App. No. 8562/79, 8 Eur. H.R. Rep. 425 (1986); X v. Sweden, App. No. 10671/83, 8 Eur. H.R. Rep. $269-70$ (1986); Muller v. Austria, App. No. 5849/72, 3 Eur. Comm'n H.R. Dec. \& Rep. 25, 29-31 (1975).

251. Stretch v. United Kingdom, App. No. 44277/98, 38 Eur. H.R. Rep. 12, 205-07 (2003).

252. See, for example, Telyatyeva v. Russia, where the delay of almost two years in executing an order from a local court that a local authority must provide housing for the applicant, despite its claim that it had no suitable housing available, constituted a breach of Article 6 and Article 1 of Protocol 1. App. No. 18762/06, II 8, 16, Final Judgment July 12, 2007, available at http://cmiskp. echr.coe.int $/ \mathrm{tkpl} 97 / \mathrm{view}$.asp? item $=1$ \& portal $=$ hbkm\&action $=\mathrm{html} \&$ highlight $=18762 / 06 \&$ sessionid $=8756018 \&$ skin $=$ hudoc-en (last visited May 30, 2008).

253. 98 Eur. Ct. H.R. (ser.A) 9 (1986). This case involved the compatibility of a right in legislation for long leaseholders to purchase the freehold title to apartments in the Duke of Westminster's Estate in Central London with Article 1 of Protocol 1.

254. See also Tassinari v. Italy, App. No. 47758/99, II 29-43 (2003), http://www.echr.coe.int/echr (click on case-law hyperlink, then click HUDOC, then search "Tassinari v. Italy", then click on "Tassinari v. Italy" hyperlink); Saffi v. Italy, App. No. 22774/93, II $46-59$ (1999), http://www.echr.coe.int/ echr (click on case-law hyperlink, then click HUDOC, then search "Saffi v. Italy", then click on "Saff v. Italy" hyperlink); Spadea v. Italy, 315 Eur. Ct. H.R. 14, $24-28$ (1995); Mellacher v. Austria, 12 Eur. H.R. Rep. 391, 407-10 (1990); X v. Austria, App. No. 8003/77, 3 Eur. H.R. Rep. 285, 291-96 (1979). 


\section{European Union (EU) Housing Rights}

While the 1957 Treaty of Rome and subsequent European Union Treaties do not refer directly to a right to housing, much EU social policy, particularly the drive toward a single market in goods and services, has a bearing on housing rights and housing policy. The "rights talk" legal system established by the EEC Treaties of the 1950s was heavily market driven, and other moral or social considerations were at best of secondary or subsidiary relevance. ${ }^{255}$ To avoid a "race to the bottom" and in the absence of EU institutional competence (outside labor legislation) to introduce minimum standards in areas of social policy, the Community began to explore an alternative approach based on "fundamental social rights" in the $1990 \mathrm{~s} .{ }^{256}$ Although there are, as yet, no European-wide directives or measures specifically relating to housing rights, the effects of other measures can impact housing rights. Indeed, the diversity of the measures affecting housing is becoming increasingly large, including consumer protection, freedom of movement, rights of establishment, environmental protection, monetary union issues, and social policy and rights initiatives. ${ }^{257}$ As the informal meeting of the European Housing Ministers in Padua in 2003 described it:

255. Grainne de Burca, The Language of Rights and European Integration, in New Legal Dynamics of European Union 29, 29 (JoShaw \& Gillian More eds., 1995) [hereinafter New Legal Drnamics]. For the first time the human rights basis of the EU was expressed in Article 6 of the Treaty of the European Union (TEU), which proclaimed that the "Union is founded on the principles of liberty, democracy, respect for human rights and fundamental freedoms and the rule of law...." Article 7 (now Article I-59 of Treaty Establishing a Constitution for Europe) permits the EU to adopt an initiative where there appears to be a clear risk of a serious violation of the values on which the EU is founded. See Grainne de Burca, New Modes of Governance and the Protection of Human Rights, in Monitoring Fundamental Rights in the EU: The Contribution of the Fundamental Rights Agency 25, 30 (Philip Alston \& Olivier de Schutter eds., 2005) [hereinafter Monitoring FundamenTAL Rights]. See also European Union, Consolidated Versions of the Treaty Establishing the European Community, 2006 O.J. (C321) E/1 12-13 [hereinafter Consolidated Treaties]. The Preamble and Article 136 of the EC Treaty mentions fundamental social rights, specifically referring to the European Social Charter of 1961 and the 1989 Community Charter. See id. at 9, 106.

256. See Jeff Kenner, Economic and Social Rights in the EU Legal Order, in Economic ano Social Rights in the EU Charter of Fundamental Rights 7, 13-14 (Tamara Hervey \& Jeff Kenner, eds., 2003)

257. See Housing Ministers of the European Union, Interactions Between National Housing Policies and Legislation, Initiatives, and Decisions of the European Union: Reflections and Summary Report (Oct. 31, 2003), available at http://mrw.wallonie.be/dgatlp/logement/ logement_euro/Dwnld/RAPPORT\%20EUROPEEN\%20En_2003.pdf (last visited Apr. 4, 2008). 


\begin{abstract}
Although housing is not under the direct competence of the $\mathrm{EU}$, it has complex links with many important issues with EU policies such as: building norms and energy conservation, competition rules, consumer policies, taxation, for instance rules on VAT, finance policies (i.e., Basel II), social inclusion, NAPincl and Joint Inclusion Memorandums for the accession countries, social and economic rights, statistics, structural funds, and promotion of research and technological development. ${ }^{258}$
\end{abstract}

EU Regulations in the 1960s and 1970s ensured that migrating non-national workers and their dependents were entitled to the same social benefits, including access to housing, as nationals of Member States on the principle of nondiscrimination. Article 9 of Regulation 1612/68 ${ }^{259}$ recognizes the significance of access to such services for European migrant workers in the context of nondiscrimination. ${ }^{260}$ In Commission v. Germany, ${ }^{261}$ the European Court of Justice (ECJ) held that a German law making the grant of a residence permit conditional on a worker having continual housing in the host state was in breach of EC law. Similarly, in Commission v. Italy, ${ }^{262}$ a restriction of access to reduced mortgage rates and other access to social housing, based on a requirement of Italian nationality, residence qualifications, and the granting of social housing for those near to their place of work, was held in breach of rules on rights to establishment under Article 52 and Article 59 of the Treaty of Rome. There are legally defined steps at the EU level to harmonize the conditions of asylum-seekers across Europe, including to

258. See European Housing Ministers, Communiqué Final: Housing Policies and European Integration Problems and Prospects 2003, available at www.eu2004.ie/templates/document_file asp? $i d=4785$ (describing the interaction between issues such as freedom of movement and discrimination with housing).

259. Council Regulation 16 12/68, art. 9, 1968 O.J. (L257) 2 (EEC), amended by Council Regulation 2434/92 1992 O.J. (L245) 1.

260. For cases on this Regulation, see http://curia.eu.int/jurisp/cgi-bin/form.pl (last visited Apr. 4, 2008).

261. Case 249/86, Comm'n v. Germany, 1989 E.C.R. 1263.

262. Case 63/86, Comm'n v. Italy, 1988 E.C.R. 29. 
standardize housing conditions, ${ }^{263}$ to recognize the rights and status of thirdcountry nationals, ${ }^{264}$ and to develop a common policy on illegal immigrants. ${ }^{265}$

Perhaps the closest step to actual housing rights in EU instruments is contained in the EU Charter of Fundamental Rights, which was "jointly and solemnly proclaimed" at Nice by the Presidents of the European Parliament, the Council, and the Commission in December 2000. ${ }^{266}$ While the Charter does not include a specific right to housing, Article 34 on social security and social assistance states:
3. In order to combat social exclusion and poverty, the Union rec- ognises and respects the right to social and housing assistance so as to ensure a decent existence for all those who lack sufficient re- sources, in accordance with the Rules laid down by Community law and national laws and practices. ${ }^{267}$

Article 34(3) draws on point 10 of the EU Community Charter of the Rights of Workers 1989, Article 13 of the European Social Charter and Articles 30 and 31 of RESC. The Union must respect the Charter in the context of policies based on Ar-

263. Council Directive 2003/9, Laying Down Minimum Standards for the Reception of Asylum Seekers, 2003 O.J. (L031) 18. See also Communication from the Commission of 3 June 2003 Towards more accessible, equitable and managed asylum systems, COM (2003) 315 final (June 3, 2003); Communication from the Commission of 26 March 2003 on the common asylum policy and the Agenda for protection, COM (2003) 152 final (Mar. 26, 2003); Statewatch, supra note 174.

264. See Council Directive 2003/109, 2004 O.J. (L16) 44 (EC).

265. See Communication from the Commission to the Council and the European Parliament on a common policy on illegal immigration. COM (2001) 672 final (Nov. 15, 2001).

266. See 2004 O.J. (C310) 3; Robin White, Social Security, in The EU Charter of Fundamental Rigrts 320 (Steven Peers \& Angela Ward eds., 2004); Olivier De Schutter \& Natalie Boccadoro, Le droit au logement da's l'Union Européenne 9, 22 (CRIDHO, Working Paper No. 2005/2, 2005).

267. Charter of the Fundamental Rights of the European Union, art. 34(3), Dec. 18, 2000, 2000 O.J. (C364) I. The wording of Article 34(3) is distinctive in the EUCFR, in that it states that a specific right to social and housing assistance is recognized and respected. For instance, Article 34(1) in relation to social security, merely states that the "Union recognizes and respects the entitlement to social security benefits and social services providing protection in cases such as maternity, illness, industrial accidents, dependency or old age." $I d$. The EUCFR has now been incorporated into Part II of the Treaty Establishing a Constitution for Europe. See Treaty Establishing a Constitution for Europe, Oct. 29, 2004, 2004 O.J. (C310) 41. The Charter housing assistance provisions may be limited under Article 34(2): "Everyone residing and moving legally within the European Union is entitled to social security benefits and social advantages in accordance with Community law and national laws and practices." Charter of Fundamental Rights of the European Union, art. 34 I 2, 2000 O.J. (C364) 16. 
ticle 137(2) of the Treaty establishing the European Community. ${ }^{268}$ Since 2001 the Charter has been invoked in all legislative proposals of the Commission ${ }^{269}$ and since 2005, in the Impact Assessments of all Commission legislative and major policydefining proposals. ${ }^{270}$ However, it has been pointed out that the ECJ remains cautious about the legal status of the Charter, ${ }^{271}$ while its integration into the Open Method of Coordination in relation to Social Inclusion has been nonexistent. ${ }^{272}$

European Council Directive 2000/43/EC of June 2000 promotes the implementation of the principle of equal treatment between persons irrespective of racial or ethnic origin (excluding noncitizens of EU states) ${ }^{273}$ and specifically, "shall apply to all persons, as regards both the public and private sectors, including public bodies, in relation to: ... (h) access to and supply of goods and services which are available to the public, including housing." ${ }^{274}$

In order to comply with the Directive, Member States shall take the necessary measures to ensure that "any laws, regulations, and administrative provisions con-

268. For explanations of the Charter, see Draft Charter of Fundamental Rights of the European Union, Oct. 11, 2000, http://www.europarl.eu.int/charter/pdf/04473_en.pdf (these explanations have been prepared at the instigation of the Praesidium. They have no legal value and are simply intended to clarify the provisions of the Charter) (last visited Mar. 20, 2008).

269. See Oliver de Schutter \& Philip Alston, Introduction Addressing the Challenges Confronting the EU Fundamental Rights Agency, in Monitoring Fundamental Rights, supra note 255, at 4.

270. European Commission, Impact Assessment Guidelines, SEC (2005) 791 (June 15, 2005), available at http://ec.europa.eu/governance/impact/docs/key_docs/sec_2005_0791_en.pdf; Communication from the Commission: Compliance with the Charter of Fundamental Rights in Commission Legislative Proposals-Methodology for Systematic and Rigorous Monitoring, COM (2005) 172 final (Apr. 21, 2005).

271. See Grainne de Búrca, The European Court of Justice and the Evolution of EU Lau, in THE State of the European Union: Law Politics and Society 48, 68 (Tanja A. Börzel \& Rachel A. Cichowski eds., 2003).

272. See KenNa, supra note 134. Social housing provisions have been recognized in the EU as a service of general economic interest. They are exempted from the full application of the Treaty with regard to competition law and State aids. See Communication from the Commission Implementing the Lisbon Community Programme: Social Services of General Interest in the European Union, COM (2006) 177 final (Apr. 26, 2006).

273. See Council Directive 2000/43, 2000 O.J. (L180) 22. Article 13 of the Amsterdam Treaty conferred to the European Community the powers to take measures to fight discrimination on grounds of sex, race/ethnic origin, religion/belief, disability, age, and sexual orientation. Arising from this Article an important legal development has taken place with powerful consequences for those who face discrimination in relation to access to housing. See European Commission, Action Against Discrimination, Civil Society, http://ec.europa.eu/employment_social/fundamental_rights/ index.htm (last visited Mar. 21, 2008).

274. Council Directive 2000/43, supra note 273, at art.3(1)(h). 
trary to the principle of equal treatment are abolished."275 Further, "Member States shall adopt the laws, regulations and administrative provisions necessary to comply with this Directive by 19th July $2003 \ldots . .276$ and "Member States shall communicate to the Commission by 19 July 2005, and every five years thereafter, all the information necessary for the Commission to draw up a report to the European Parliament and the Council on the application of this Directive."277

In 2004, the "Gender Directive," a Council Directive implementing the principle of equal treatment between women and men in the access to and supply of goods and services, addressed housing. ${ }^{278}$ The EU Unfair Contract Terms Directive 1993/93/13/EEC has had an impact on housing rights in many EU states ${ }^{279}$ and is creating a body of jurisprudence across Europe in relation to house purchase and tenancy agreements. ${ }^{280}$

Clearly, a developing corpus of law, jurisprudence and literature on housing rights is developing, particularly in Europe and especially within the Council of Europe.

\section{Some Conclusions}

The disparate nature of the developments in globalization, housing systems, and housing rights do not permit a neat conclusion to this brief study. Instead, one can merely point to key developments within the rapidly changing landscape. All these areas require further research in the context of the promotion of housing rights.

\section{A. Major Changes in Housing Systems}

The globalization of neo-liberalism, production, consumerism, technology, and the speed of change are relentless developments, but a counter movement has been spawned. Driven by powerful forces, globalization is creating homelessness and greater impoverishment among the majority of the world's population, despite some advances for countries which have embraced industrialization and uni-

275. Id. at art. 14(a).

276. Id. at art. 16 .

277. Id. at art. 17.

278. See Council Directive 2004/113, 2004 O.J. (L373) 37, 38 (EC) (implementing the principle of equal treatment between men and women in the access to and supply of goods and services). Member States must transpose the Directive by December 21, 2007 at the latest.

279. See Khatun v. Newham London Borough Council [2003] EWHC 2326.

280. See Report From the Commission on the Implementation of Council Directive 93.13.EEC of 5 April 1993 on Unfair Terms in Consumer Contracts, COM (2000) 248 final (Apr. 27, 2000). 
versal welfare provision. The greatest impacts appear to be on women's lives, whether in the new global industries or in trying to cope with migration, poverty, and homelessness. As a result of the development of capital and interest rates worldwide, the biggest housing price bubble in history exists today. More household equity is now held in housing than in shares, cash or possessions, and the consequences of a housing price crash could be catastrophic for many of the world's people. This is particularly relevant for those homeowners in low-paid, casual, and precarious employment, who often rely on the sub-prime lending market and who are exposed to eviction on default. ${ }^{281}$ Indeed, the sub-prime lending market is often targeted at those who occupy the lowest positions in the labor market or are excluded generally, reflecting the U.S. experience where African American and Hispanic households now are most severely affected by a downturn in the economy and housing market and the resulting repossessions. ${ }^{282}$

Globalized housing corporations, World Bank drives for privatization and property registration, integration (with major difficulties) of mortgage markets, reordering of cities, and the creation of more slums, all have major effects on housing systems. So too, problems arise for states seeking to counter the worst effects of globalization from the newly imposed minimalist welfare roles of the state and the rise of "governance," networks, and "soft law" approaches to regulation in place of traditional democratic government legislative action at the national level. There is growing stratification of housing tenure allied to income, class, ethnicity, locations, and increasing land costs, creating difficulties for new purchasers, and of course, much homelessness in all cities (even in Europe where migrants and refugees are increasingly visible).

Housing rights are becoming an important part of international human rights law and principles, especially at the European level. Guaranteeing minimum standards and the progressive realization of such rights as resources permit, they offer an additional paradigm for the establishment and evaluation of housing policies. At a more specific level, some rights instruments (including civil and po-

281. See Vikas Bajaj \& Ford Fessenden, What's Behind the Race Gap?, N.Y. Tımes, Nov. 2, 2007, available at $\mathrm{http}: / / \mathrm{ww}$ w.nytimes.com/2007/11/04/weekinreview/04bajaj.html.

282. According to the U.S. Census Bureau, whereas the national homeownership rate rose from 64.7 percent in 1995 to 68.8 percent in 2006, the rise was greater among African American (42.7 to 47.9 percent) and Hispanic households ( 42.1 to 49.7 percent). According to the Federal Reserve's Survey of Consumer Finances, the rise in homeownership from 1995 to 2004 was 6 percent in lower-income census tracts versus 4 percent in higher-income tracts. See John Kiff \& Paul Mills, Money for Nothing and Checks for Free: Recent Developments in U.S. Subprime Mortgage Markets 5 (International Monetary Fund, Working Paper WP/07/188, 2007). 
litical rights) are leading to particular housing scenarios being examined as violations of enforceable rights, with penalties and remedies being imposed. At the EU level, housing rights are being imposed in areas of nondiscrimination and early attempts to develop harmonized fundamental rights across Europe.

\section{B. Mediating the Excesses of Neo-liberal Globalization}

While state interventionist policies to mediate the worst excesses of neo-liberal globalization have become more politically difficult and costly at the national level, they are not impossible. The UNCHS Report on Cities in a Globalizing World points out that while the orthodox view is that it is the role of government to manage the macroeconomy to enable the market to address the needs of the poor, in practice, equity and political pragmatism help to justify measures that support the poor. ${ }^{283}$ For instance, in Thailand, the economic recession in the 1990s resulted in social investment funding from the World Bank and other donors. "Hence, it is not clear that the reductions in public expenditure have resulted in an inability of the state to support housing finance where the institutions of local government and civil society are strong enough to demand resources, and demonstrate the effective use of such resources." ${ }^{284}$

In Europe, Gøsta Esping-Andersen points out that different strategic responses to globalization emerge from different models of welfare states-liberal, conservative-corporatist, and social democratic. ${ }^{285}$ Doling and Ford, in their seminal study of experiences of globalization and home ownership in eight European countries, identify similar trends in relation to housing policy responses based on a "strong globalisation" model and a "weak globalisation" model. ${ }^{286}$ In the "strong globalisation" model, the massive power of international capital creates fear in states that they have lost much of their leverage over investment decisions, that international capitalists may engage in "regime shopping" and social dumping, where they will locate in countries with low taxation and weak labor rights. In this model, the actions of government are driven by a logic of globalization. Here, home ownership, once a source of stability, security, and investment, becomes a site for uncertainty and risk due to changing work patterns and reduced welfare

283. U.N. Centre for Human Settlements, supra note 76 , at 83.

284. Id. at 84 .

285. See generally Gøsta Esping-Andersen, The Three Worlds of Welfare Capitalism (1990); Welfare States in Transition: National Adaptations in Global Economies 33 (Gøsta EspingAndersen. ed., 1996).

286. See John Doling et al., Globalisation and Home Ounership, in Globalisation and Home OWNership, supra note 69, at 3 . 
protection. In the "weak globalisation" model, the risks from globalization are mediated by social norms and state action, where risk is conceptualized as socially constructed rather than individual. ${ }^{287}$

The "ideal type" housing policy responses to globalization are defined by the model of welfare system in place. ${ }^{288}$ Thus, the neo-liberal model would address unemployed homeowners with mortgages as a feature of the market, to be resolved by a minimum of state intervention and only as a last resort. The social democratic model shifts the focus from the private to the public sector, with a public responsibility to ensure socially acceptable outcomes. The state would ensure adequate income, even in unemployment, for housing costs to be met. The conservative-corporatist model would also establish systems to protect the home buyer, but maintain status differentials. The "Latin rim" welfare model ${ }^{289}$ places reliance on family and church to provide assistance, rather than the state. Typically, the legal process of mortgage debt recovery is drawn out and lenders organize their affairs to protect themselves against widespread default. ${ }^{290}$

In some European countries, the power resources of the labor movement and the political forces supporting the post-war class compromise may still be strong enough to defend existing entitlements and to resist the dismantling of the welfare state. Jürgen Habermas urges a European Constitution as a means of creating a public sphere of European politics and protecting the gains of the Union.

In Western Europe ... the political tradition of the workers' movement, the salience of Christian social doctrines and even a certain normative core of social liberalism still provide a formative background for social solidarity. In their public self-representations, So-

287. Id. at 15. The level of support with housing costs to unemployed homeowners with mortgages is seen as an indicator of which approach is taken by States. Risks to homeowners are increasingly structural as well as cyclical and in some countries are being ratcheted upwards. Id. at 14-17.

288. Bo Bengtsson, Housing as a Social Right: Implications for Welfare State Theory, 24 Scandinavian PoL. Sruv. 255, 270 (2001). Bengtsson recognizes that the right to housing must also be addressed in the market context. Drawing on a study of five Nordic countries' housing policies, Bengtsson plots a course of housing policy from an "establishment" phase from the 1920s, a "construction" phase after 1945 , a "saturation" phase after the 1970 s, and the privatization or "retrenchment" phase from the 1990s. Brendan Edgeworth points out that European post-war welfare States were managing risks to people and families rather than vindicating individual rights. See Brendan Edgeworth, Law, Modernity, Postmodernity: Legal Change in the Contracting State 90 (2003).

289. See Stephan Liebfried, Towards a European Welfare State?, in New Perspectives on the Welfare State in Europe 133, 141 (Catherine Jones ed., 1993).

290. See Hannu Ruonavaara, Finland, in Globalization and Home Ownership, supra note 69, at $227-29$. 
cial and Christian Democratic parties in particular support inclusive systems of social security and a substantive conception of citizenship .... ${ }^{291}$

Indeed, while there is a perceived connection between globalization and reductions in state spending and the tightening of eligibility for assistance in key areas such as homelessness, some analyses of the actual situation in Europe reveal a more complex scenario. A FEANTSA Report in 2005 shows that European states continue to act significantly in relation to homelessness:

Our analysis of the changing role of the state in relation to housing and homelessness challenges, at several levels, the hegemony of neo-liberal ideology. The findings of the Working Group clearly demonstrate that the state in Europe (in all its various forms) continues to exercise - albeit differentially - considerable clout in respect to welfare delivery generally and in respect to housing and homelessness specifically. The variable national patterns of welfare delivery and intervention set up in the immediate post-war period continue to exercise a conditioning, if not determinate, influence on the present role of the state. We can perhaps regret that state involvement in terms of policies and resource commitment to the alleviation and prevention of homelessness has not received and still does not receive greater priority and attention, but there is little evidence to suggest a wholesale retreat or retrenchment. ${ }^{292}$

Clearly, there are major opportunities to mitigate the effects of global neoliberalism in housing systems within developed welfare states. But where these do not exist, countries are exposed to the naked pressures of neo-liberalization. Housing rights jurisprudence, implementation, and monitoring systems can provide some protection.

\section{Some Observations}

Challenging the World Bank and globalized neo-liberalism promoting property registration, privatization, markets, and capital movement, housing rights

291. Jürgen Habermas, Why Europe Needs a Constitution, 11 New Left Rev. 5, 10 (2001).

292. Doherty et al., supra note 122, at 22. 
advocates seek guarantees of nondiscrimination and equality in relation to registration and access to titles. Equally, the democratic and state ownership of land registries is required to ensure that they are in a position to comply with international human rights obligations of states. ${ }^{293}$ Indeed, land registry systems could be used by progressive states to examine and monitor patterns of ownership to ensure that situations of inequality and social exclusion, class, gender, ethnic, and other discrimination or segregation are not developing. Control of speculation in land may be required to protect the right to affordable housing. ${ }^{29 t}$

The zoning, planning, and building control measures exercised by the state are critical elements in the development of housing markets, and these markets actually require a legal and regulatory framework that only governments can provide. ${ }^{295}$ Even in the age of globalization, states retain a variety of tools to influence housing policy and can promote housing rights through planning, ${ }^{296}$ zoning, public expenditure, taxation measures, and other measures. However, the World Bank pointed out in Land Policies for Growth and Poverty Reduction that in many developing countries there has been a legacy of sectional and vested interests having undue political influence in relation to land zoning and planning applications, as well as state financial support for different tenures. ${ }^{297}$

Housing rights advocates promote legally enforceable rights to access, equality, nondiscrimination, quality, high standards, habitability, etc. There needs to be clear, accountable, and well defined responsibilities on corporations and states in the area of regulation. Rather than self-regulation or ineffective co-regulation of housing systems and housing finance agencies, penalties and sanctions for viola-

293. Throughout October 2005, local, national and regional organizations, social movements, NGOs and academic institutions were called to organize public actions and events to denounce destructive impacts of neo-liberal development policies and economic globalization (such as: budget cuts, forced evictions, land speculation, and privatization of social housing and utilities) on people's housing and land rights across the planet. See Habitat International Coalition, Housing and Land Rights Day 2006, http://www.hic-net.org/indepth.asp? PID =61 (last visited Apr. 4, 2008).

294. Indeed, the UNCESCR requests information on a number of issues in its monitoring of Article 11 of the ICESCR. See ECOSOC, Revised General Guidelines Regarding the Form and Content of Reports To Be Submitted To The Committee by States Parties under Articles 16 and 17 of the International Covenant on Economic Social, and Cultural Rights, art. 11, UN Doc. E/C.12/1991/1 (June 17, 1991).

295. See World Bank, World Development Report 1991: The Challenge of Development, 41 Econ. Dev. \& Cultural Change 430, 430 (1991).

296. See, e.g., Juli Ponce, Land Use Law, Liberalization, and Social Cohesion Through Affordable Housing in Europe: The Spanish Case, 36 URB. Law 317 (2004) (for a contemporary analysis of the use of planning law to combat social exclusion in housing).

297. See Klaus Deininger, Land Policies for Growth and Poverty Reduction 183-86 (World Bank 2003). 
tions of housing rights must not be merely symbolic, but based on the Limburg Principles on the Implementation of the International Covenant on Economic, Social and Cultural Rights ${ }^{298}$ and The Maastricht Guidelines on Violations of Economic, Social and Cultural Rights. ${ }^{299}$

Housing rights advocates seck the end of discrimination in access to housing finance as a means of access to housing. Interest rates should be affordable and the use of sub-prime lending to people who have poor credit histories or casual employment must not discriminate through higher interest rates, thus doubly denying equality in the housing system. Improvident lending should be discouraged by denying foreclosures and repossessions where borrowers default. There is a critical need to address the housing rights guarantees of international instruments to this group in light of the housing bubble worldwide and falling U.S. house prices. In the event of mortgage default and repossession, housing rights, including the prevention of homelessness, must be guarantecd. For those who are unable to secure housing finance, appropriate social and affordable housing must be provided.

Consumer protection in this age of globalized housing finance corporations is a critical element of housing rights in market societies. This applies across the world as globalized housing finance impacts on housing access. Since 1987, there have been rules to harmonize consumer credit in Europe, although home loans were excluded from the scope of the directive. ${ }^{300}$ This is a major obstacle to housing rights within the European Union, and one which is rarely highlighted by housing rights advocates. ${ }^{301}$

Housing rights advocates assert the need for legally defined and enforceable standards in housing quality and environment with adequate and affordable water and other services. ${ }^{302}$ Democratic control over planning and standards as well as compliance with international housing instruments are necessary. The objective of social inclusion for all should be an integral element of legally defined and enforced planning and infrastructure systems, particularly to counter the

298. Limburg Principles, supra note 205.

299. Maastricht Guidelines, supra note 206.

300. See Council Directive 87/102, 1987 O.J. (L042) 48 (EEC) (for the approximation of the laws, regulations, and administrative provisions of the Member States concerning consumer credit).

301. The European Union has been developing consumer protection law since Art. 153 was inserted in the Treaty of Amsterdam in 1997. See Communication from the Commission to the European Parliament, the Council, the Economic and Social Committee and the Committee of the Regions: Consumer Policy Strategy 2000-2006, at 2, COM (2002) 208 final (June 8, 2002).

302. See U.N. Econ. Comm'n for Eur. [UNECE], ECE Compendium of Model Provisions for Building Regulations, U.N. Doc. ECE/HBP/81/Rev.1 (Jan.1996). 
"mosaics of inequality," which are developing in the globalization of some cities. The requirements set out in General Comment No. 4 on housing adequacy need to be incorporated into infrastructure planning, as well as the HIC Housing Rights Toolkit. The standards and benchmarks developed by the Council of Europe Committee on Social Rights can provide effective measurements of the realization of the right to housing in key areas and are legal, transparent, and accessible. Many vulnerable people or migrants who are denied access to low-cost social housing are often forced into sub-prime borrowing, with little consumer or housing rights protection. These people are situated at the fault-line between private market housing and social housing.

Housing rights advocates seek to create legally enforceable, non-discriminatory rights to housing assistance for those in need of housing and homeless people. In some situations, the positive obligations of the state to prevent "inhuman and degrading treatment" under Article 3 of the ECHR have been used to assist homeless and destitute people. ${ }^{303}$ Housing rights should include special provisions for people with special needs. Housing rights also require policies of integration, quality, and affordability in social housing provision. ${ }^{304}$

\section{Can Housing Rights Instruments Deal with Globalization?}

Rhoda Howard-Hassmann echoes much of what passes for conventional wisdom today claiming that globalization is inevitable. It is seen as the only path to long term growth, even though in the short term the process of globalization is causing human rights abuses. ${ }^{305}$ However, globalization speeds up access to the very idea of human rights through the Internet, as well as international publicity of human rights abuses. This enables the formation of global social movements in favor of human rights and the globalization of NGOs such as Greenpeace and Oxfam. Howard-Hassmann proposes that the "leapfrogging" of human rights across time and space can partially alleviate the problems caused by globalization. ${ }^{306}$

Richard Falk suggests that a subaltern discourse on human rights encompasses the full panoply of human rights, with the UDHR laying the foundation

303. See Regina v. Secretary of State for the Home Department (Appellant) UKHL 66 (2005), available at 2000 WL 280234, ๆ6.

304. See Council of Europe, European Committee of Social Rights: Conclusions 2005-Volume 1, art. 31, available at http://www.coe.int/T/E/Human_Rights/Esc/2_ECSR_European_Committee_of _Social_Rights/.

305. See Howard-Hassmann, supra note 11 , at 1.

306. Id. at 38-39. 
for superseding the dominant globalization discourse. There is a core demand, from a strictly materialist perspective, within Article 25(1): "Everyone has the right to a standard of living adequate for the health and well-being of himself and of his family, including food, clothing, housing and medical care and necessary social services ...." ${ }^{307}$

U.N. Special Rapporteur Miloon Kothari pointed out in 2003 that while the debate continues at the international level on whether or not globalization can bring benefits to the world's poor, the fact remains that the deepening inequalities of income and opportunity between and within nations has led to an increase in the number of people without adequate and secure housing:

It is time to rethink the current global economic and social policies and to recommit ourselves to the human rights principles and standards that offer the only real paradigm for improving the lives of millions of the poor...

Every woman, man, youth and child has the human right to a secure home and community in which to live in peace and dignity. This human right has received global recognition and is firmly established in a number of international human rights instruments, most notably in the International Covenant on Economic, Social and Cultural Rights....

Notwithstanding the constraints and difficulties placed upon them, central governments still have an important role to play in reconciling macroeconomic policies with social objectives, keeping in mind the primacy of their human rights obligations. Governments have the responsibility to make targeted interventions in order to ensure universal access to public services, including water and sanitation, on a fair and equitable basis; this is fundamental for the fulfilment of the right to adequate housing. ${ }^{308}$

307. Falk, supra note 34 , at 71.

308. Miloon Kothari, Privatizing Human Rights: The Impact of Globalisation on Access to Adequate Housing, Water and Sanitation II 1-4 (2003), available at http://www.hic-net.org/articles .asp? PID= 194. 
In a similar vein, the UNCESCR has addressed the role of the state in protecting housing rights in the age of globalization:

The view that States or other actors cannot be held responsible for violations of economic, social and cultural rights is seriously being questioned as a flawed premise, both empirically and conceptually. ... At a minimum, States parties are obliged to realize minimum standards relating to each of the rights utilizing available resources in an effective manner. The Limburg Principles on the Implementation of the International Covenant on Economic, Social and Cultural Rights (1986) and the Maastricht Guidelines on Violations of Economic, Social and Cultural Rights (1997) drawn up by groups of experts, and increasingly gaining in currency before United Nations forums, have expanded on the General Comment. The Maastricht Guidelines recognize a triad of obligations- - to respect, protect and fulfil. As such, when State conduct falls short of these obligations, or fails to achieve the required level of realization of rights, it is responsible for violating the rights in the ICESCR. Violations can occur either through commission or omission. The jurisprudence of the Committee on Economic, Social and Cultural Rights that recognizes "minimum core obligations" on the part of States parties are echoed by the Maastricht Guidelines. Such core obligations have to be fulfilled irrespective of resource or other constraints. In determining whether a State party has utilized the 'maximum of its available resources' attention shall be paid to the equitable and effective use of and access to available resources. It is also significant that the Maastricht Guidelines recognize violations by States resulting from their failure to exercise due diligence in controlling the behaviour of non-State actors, such as transnational corporations, over which they exercise jurisdiction, when such behaviour deprives individuals of their economic, social and cultural rights. ${ }^{309}$

309. ECOSOC, Sub-Comm. on Promotion \& Prot. of Human Rights, The Realization of Economic, Social and Cultural Rights: Globalization and Its Impact on the Full Enjoyment of Human Rights, U.N. Doc. E/CN.4/sub.2/2000/13 (June 15, 2000) (prepared by J. Oloka-Onyango \& Deepika Udagama), available at http://www.unhchr.ch/huridocda/huridoca.nsf/(Symbol)/ E.CN.4.Sub.2.2000.13.En? Opendocument. 
While this model, the "transmission belt" of international human rights being adopted into national law, is widely accepted, it faces major and growing obstacles from the new forms of governance, patterns of law, and particularly from increasing forms of soft law regulation. This classical approach to international human rights law, where states accept, ratify, and implement the international human rights norms through national laws and other measures, is based on a liberal legalist approach. It views laws as coherent and autonomous systems of norms "that operate[] as an effective tool of social engineering to promote or protect individual freedom." 310 Anderson points out that while there has been a huge increase in international and national charters of rights, any discussion of states' constitutional authority "now has to take account of the disciplining effects of the global economy, and the power networks formed by transnational corporations." ${ }^{311}$

Indeed, this liberal legalist (and occasionally nationalist) constitutional approach is in this new global climate no longer relevant to understanding the role of law in key areas of society, such as housing. For instance, constitutional and national laws may only apply to citizens. The position of the growing numbers of noncitizens, migrants, asylum-seekers, and refugees, often without any constitutional or legal protection, let alone housing rights, is growing in significance. It may no longer be appropriate to rely on national laws and constitutions to deal with the complex area of rights enforcement. The concepts of liberal legalism (reflecting the classical, historical liberal distrust of the state) and constitutional charters, which are principally concerned with the limitation of state actions, need to be radically reviewed. Equally, the traditional reluctance of courts to impose public obligations on private bodies for fear of constitutional breach needs to be re-examined. Further, State and constitutional rights development must now incorporate positive obligations on states to intervene and regulate private actors and national and international corporations. ${ }^{312}$ Ultimately states and courts must "trump" private property rights with the panoply of human rights, including socio-economic rights. States must regulate property, both real and intellectual, and the contemporary forms of capital with enforceable laws and obligations at a macro and micro level.

310. Anderson, supra note 120 , at 6 .

311. Id.

312. The European Convention on Human Rights and Fundamental Freedoms places positive obligations on States to take action in a number of a reas of rights, such as preventing inhuman and degrading treatment resulting from homelessness among failed asylum-seekers. See Regina v. Secretary of State for the Home Department and another (Respondents) ex parte A nufrijeva (FC) (Appellant) [2003] UKHL 36. See also, Lopez-Ostra v. Spain 20 Eur. H.R. Rep. 277 (1995) (for protection of home and family life). 
Of course, the principle of equating multibillion dollar transnational corporations with the same legal status as rights-bearing individuals is increasingly acting to undermine human rights development. ${ }^{313}$ One major weakness in the rights system for housing rights is that legal liberalism formally treats owners of houses or gardens the same as owners of large-scale development land, large capital portfolios, or corporate equity. Perhaps it is now time to engage with the substantive rather than formal elements of housing rights so that this clear conceptual conflict can be seen. Equating land rights, registered as property rights, with housing rights is a simplistic and reductionist approach.

One recent case illustrates the limitations of the liberal legalist-defined housing rights approach in dealing with structural housing issues at individual level. In Hutten-Czapska v. Poland ${ }^{31+}$ the State-imposed ceiling on rent levels for Polish private tenants (600,000 to 900,000 tenants benefitted) was found to be too low to enable landlords to recoup their maintenance costs, let alone make a profit. While the court accepted that the measure to protect tenants was justified, the Polish legislation did not secure any mechanism for balancing the costs of maintaining the property and the income from rent (which covered 60 percent of these costs). This created a disproportionate and excessive burden on the applicant and constituted a violation of Article 1 of Protocol 1 of the Convention on peaceful enjoyment of possessions. It was not, however, up to the court to indicate what a reasonable rent would be.

The ECtHR unanimously held that the violation had "originated in a systemic problem connected with the malfunctioning of domestic legislation in that it had imposed, and continued to impose, on individual landlords restrictions on increases in rent for their dwellings, making it impossible for them to receive rent reasonably commensurate with the general costs of property maintenance." ${ }^{15}$ It also held that "in order to put an end to the systemic violation identified in the present case, the respondent State must, through the appropriate legal or other measures, secure a reasonable level of rent to the applicant and other persons similarly situated, or provide them with a mechanism mitigating the above-mentioned consequences of the State control of rent increases for their right of property." ${ }^{\text {"16 }}$

In a partly concurring, partly dissenting opinion, Judge Zupančič raised im-

313. See Anderson, supra note 120 , at 125.

314. Hutten-Czapska v. Poland, 2006-VIII Eur. Ct. H.R. 628.

315. Id. at $\mathbb{\text { I }} 6$.

316. Id. 
portant questions for the ECtHR when addressing structural changes in society involving global influences such as deregulation of rents, affecting rights:

In order to respect the spirit of the Convention, we may take these political hesitations seriously and ask the next question. Is it better for Poland to be condemned in this Court 80,000 times and to pay all the costs and expenses incurred in 80,000 cases, or is it better to say to the country concerned:

"Look, you have a serious problem on your hands and we would prefer you to resolve it at home ... ! If it helps, these are what we think you should take into account as the minimum standards in resolving this problem ..."? ...

In the end, and quite apart from the general question addressed above, I have voted against point number four of the operative provisions and its reference to paragraph 239 of the judgment. The objectionable paragraph 239 reads as follows: "... the Court considers that the respondent State must above all, through appropriate legal and/ or other measures, secure in its domestic legal order a mechanism maintaining a fair balance between the interests of landlords, including their entitlement to derive profit from their property ..."

The travaux préparatoires of Protocol No. 1 amply demonstrate the hesitations different prospective signatories had concerning its Article 1 . These hesitations concerned the question whether the right to property is a human right at all. A fortiori, the right to derive profit by merely owning an apartment building cannot be seen as a human right....

In other words, the question whether "peaceful enjoyment of one's possessions" implies the "entitlement to derive profit from one's property" must be answered in the negative. This is not the place to discuss the "social function of property", although a clause to that effect is an integral part of many modern constitutions. Suffice it to say that a sheer profit for the landlord—in other words, income not 
derived from his services-is, for the tenant, of necessity a payment that is not reciprocated by a benefit.

How can that be a landlord's human right?'317

This case presents a clear challenge to the relevance of housing and human rights instruments in the face of structural global pressures. In this case it involved the abolition of rent controls for poor people, in line with World Bank policies. Of course, the landlord could have been a global corporation, and the court would have reached the same conclusion. But the core issue remains whether housing rights advocates can rely on courts to give effect to legally defined housing and other human rights in the face of international global economic ideologies.

In reconciling housing rights and globalization, it is important to remember that:

The market is not a naturally occurring phenomenon but an amalgam of the rules of property and contract that constitute it, including those of international trade and investment. Economic activities take place within a framework that is produced by political choices, is continually shaped by the State and is dependent on its enforcement agencies. Courts in particular play a significant role in protecting economic power. ${ }^{318}$

Implementing, integrating, and enforcing housing rights in increasingly complex housing systems that are experiencing pressures from globalization, remains a significant challenge for housing rights advocates. ${ }^{319}$ Indeed, Paul O'Connell argues that one cannot be committed to the protection of fundamental human rights and at the same time be quiescent in the dominant model of globalization. ${ }^{320}$ The cur-

317. Hutten-Czapska v. Poland, 2006-VIII Eur. Ct. H.R. 628 (J. Zupančič, concurring in part, dissenting in part).

318. John Baker et al., Equality, From Theory to Action 126 (2004).

319. On the delights and dangers of rejecting law reform and rights approaches to globalization as instruments for social change on grounds of cooptation or deradicalization, see Orly Lobel, The Paradox of Extra-Legal Activism: Critical Legal Consciousness and Transformative Politics, 120 Harv. L. Rev. 937 (2007). see also Neil Stammers, Social Movements and the Social Construction of Human Rights, 21 Hum. Rrs. Q. 980, 1002 (1999).

320. See Paul O' Connell, On Reconciling Irreconcilables: Neo-liberal Globalisation and Human Rights, 7 Hum. Rts. L. Rev. 483 (2007). 
rent, dominant model of globalization, neo-liberal globalization, is inherently inimical to the protection of human rights. He suggests that advocates of human rights (be they grassroots campaigners, academics, or members of the global human rights officialdom) must take a strong stance against prevailing orthodoxies in order to genuinely advance and entrench a culture of human rights protection.

Of course, the ICESCR enshrines states' obligations to undertake to the maximum of available resources all appropriate legislative, administrative, and other measures for the implementation of the right to housing, the meeting of minimum core obligations, and the progressive realization of housing rights.

Perhaps it is also time for a fresh consideration of the meaning of rights and the historical and ideological alignment of housing rights with property rights. The distinction can be seen more clearly when housing rights begin to incorporate the concept of home rather than property. Indeed, the concept of "home" itself is much wider than a legal concept, and involves important subjective, cultural, emotional, social status, and social relational issues. It involves more than a permanent or temporary dwelling, but includes the human dimension of living and having relationships. ${ }^{321}$ The concept of home epitomizes situations of family, affection, love, children, and other human experiences. ${ }^{322}$ The idea of a house is usually central in the legal treatment of home, ${ }^{323}$ but it has been suggested that home needs to be conceptualized as a house plus an $\mathrm{x}$ factor. This $\mathrm{x}$ factor represents the social, psychological, and cultural values which a physical structure acquires through use as a home.

\section{[H]ome as a physical structure offers material shelter; home as a terri- tory offers security and control, a locus in space, permanence and continuity and privacy; home as a centre for self-identity offers a reflec- tion of one's ideas and values, and acts as an indicator of personal}

321. See Lorna Fox, The Meaning of Home: A Chimerical Concept or a Legal Challenge?, 29 J.L. \& Soc'y 580, 590 (2002); Lorna Fox, Conceptualizing Home: Theories, Laws and Policies 146, $167-77(2007)$.

322. Security of tenure and other housing rights are essential for children's care, development and protection of other rights. The term "development" here is taken from Article 6(2) of the Convention on the Rights of the Child, to mean physical, emotional, cognitive, social and cultural development. See Aoife Nolan, Security of Tenure from a Children's Rights Perspective, 7 Econ. \& Soc. Rts. Rev., Oct. 2006, at 22, 24.

323. Fox points out that liberal legalism cannot deal appropriately with the concept of home except in terms of property law and valuations of wealth, or criminal law prohibitions on damage to property or persons. The legal or human rights protections of privacy or inviolability of home do not define to any great extent the holistic nature of home. Of course, glorification of home in legal discourse and law has often been associated with oppression of women. 
status; and home as a social and cultural unit acts as the locus for relationships with family and friends, and as a centre of activities. ${ }^{324}$

Many of these elements of home have not yet been fully articulated or established in the domain of housing rights. Ingrid Westendorp points out that there are limitations to the effectiveness of international human rights and housing rights for women as they are based on public international law. This is based on legal liberalist concepts emphasizing freedom etc., which creates a major distinction between private and public spheres. ${ }^{325}$ Perhaps the private is in fact public in the area of housing rights.

A meaningful legal concept of home is needed to enhance housing rights approaches, which would be capable of reflecting the range of experiences which take place in homes and the complexity of experiences of living. Housing rights in the age of globalization must be addressed in this context rather than as extensions of eighteenth-century frontiersmen's law. Now, there is a challenge for housing rights advocates.

324. Fox, The Meaning of Home, supra note 321, at 590-91.

325. See Ingrid Westendorp, Women and Housing: Gender Makes a Difference (2007). 
International Journal of

\section{Feminist Approaches}

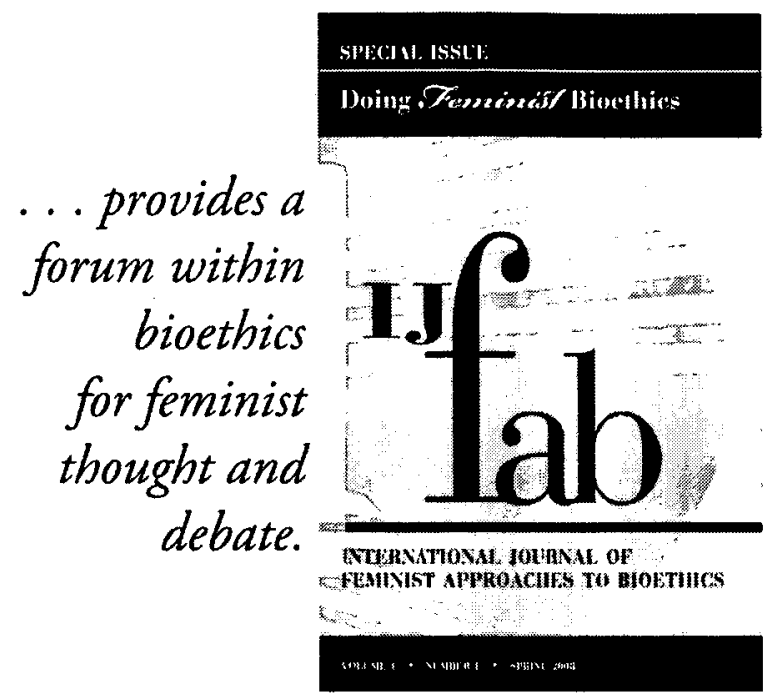

Edited by Mary C. Rawlinson

p-ISSN: $1937-4585$

e - ISSN: 1937-4577

The International Journal of Feminist Approaches to Bioethics (IJFAB) provides a forum within bioethics for feminist thought and debate. Sponsored by the International Network on Feminist Approaches to Bioethics, IJFAB welcomes feminist scholarship on ethical issues related to health, health care, and the biomedical sciences. IIFAB aims to demonstrate clearly the necessity and distinctive contributions of feminist scholarship to bioethics.

Institutions:

print $\$ 85.00$

electronic $\$ 76.50$

print \& electronic $\$ 119.00$
Individuals:

print $\$ 42.00$

electronic $\$ 37.80$

print \& electronic $\$ 46.20$

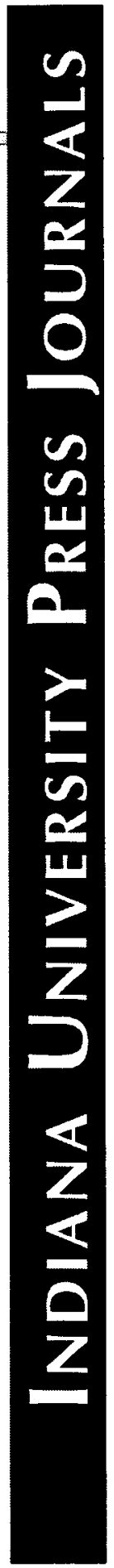

Now available

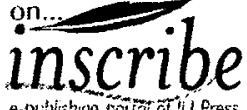

HTTP://INSCRIBE.IUPRESS.ORG 1.800 .842 .6796 